\title{
Chromophoric dissolved organic matter in summer in a coastal mariculture region of northern Shandong Peninsula, North Yellow Sea
}

\author{
Bo Yang ${ }^{\mathrm{a}, \mathrm{b}, \mathrm{c}}$, Xuelu Gao $\mathrm{Ga}^{\mathrm{a}, \mathrm{b}, \mathrm{c}, *}$ \\ ${ }^{\text {a }}$ CAS Key Laboratory of Coastal Zone Environmental Processes and Ecological Remediation, Yantai Institute of Coastal Zone Research, Chinese Academy of Sciences, \\ Yantai, Shandong 264003, China \\ ${ }^{\mathrm{b}}$ University of Chinese Academy of Sciences, Beijing 100049, China

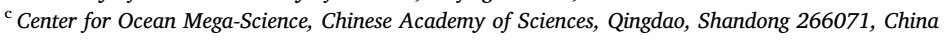

\section{A R T I C L E I N F O}

\section{Keywords:}

Spectroscopic analysis of seawater

Absorption coefficient

Fluorescent components

Composition and distribution

Biogeochemistry

Coastal waters

\begin{abstract}
A B S T R A C T
Four field cruises were carried out in a mariculture region of the northern Shandong Peninsula from June to September 2017. The concentration of dissolved organic carbon (DOC) together with the absorbance and fluorescence indices of chromophoric dissolved organic matter (CDOM) were measured. The parallel factor analysis model identified four unique fluorescent components consisting of two protein components identified as tyrosine-like C1 and tryptophan-like C2, and two humic-like components C3 and C4. The DOC, CDOM absorption coefficient at $350 \mathrm{~nm}\left(a_{350}\right)$ and protein-like components C1 and C2 exhibited obvious monthly variations particularly. However, the monthly variation of humic-like components C3 and C4 was not significantly different. Spatially, the $a_{350}$ and fluorescent components C1-C4 were higher in the nearshore area and decreased towards the offshore area. The humification index, fluorescence index and biological index indicated the predominant autochthonous and microbial sources of CDOM. In the surface water, phytoplankton was assessed as the contributor to $11.6-35.2 \%$ of the CDOM, and $9.0-37.4 \%, 9.1-37.4 \%, 7.8-18.7 \%$ and $11.4-19.9 \%$ of the CDOM were identified as C1, C2, C3 and C4, respectively. The river inputs, especially the Xin'an River, have an important impact on DOM dynamics. In the bottom water, microbial aerobic degradation of sinking biogenic particles is an important source of humic-like components, which contributed $9.1 \%, 18.7 \%$ and $48.5 \%$ to C3 in July, August and September, and $14.6 \%, 16.3 \%, 18.0 \%$ and $26.6 \%$ to C4 from June to September, respectively.
\end{abstract}

\section{Introduction}

In coastal waters, dissolved organic matter (DOM) is ubiquitous and plays a critical role in organic carbon cycle, aquatic biogeochemical processes, as well as interactions with aquatic organisms and the bioavailability of pollutants (Yamashita et al., 2013; Watanabe and Kuwae, 2015). DOM consists of a complex mixture of organic compounds of multiple sources. A significant fraction of DOM can be transported into marine water by riverine discharge (Spencer et al., 2012) and atmospheric deposition (Birdwell and Engel, 2010). These processes are referred to as allochthonous processes for marine DOM. Research data showed that rivers contribute about $0.25 \times 10^{15} \mathrm{~g} \mathrm{C} \mathrm{yr}^{-1}$ DOM to the global ocean (Spencer et al., 2012; Raymond and Spencer, 2015). Another fraction of DOM originates from marine autochthonous processes. It is mainly produced by plankton during primary and secondary production (Hansell et al., 2009). Meso-zooplankton mediates the release of DOM and up to 50\% of suspension filtered food can be released as DOM during grazing activity (Carlson and Hansell, 2014). Moreover, viral cell lysis (Suttle, 2005) and bacteria (Jiao et al., 2010) can cause the release of DOM from particulate organic matter (POM) and sediment organic matter (SOM) (Coble, 2007; Specchiulli et al., 2016).

The chromophoric DOM (CDOM) represents optically active DOM fractions, which comprises up to $70 \%$ of total DOM in the coastal region (Nieke et al., 1997). CDOM is essential in both physical and biological processes controlling light attenuation and photochemical reactions in the surface ocean, impacting the primary production, protecting organisms from UV radiation, and contributing to the organic carbon cycle due to high photoreactivity (Blough and Del Vecchio, 2002; Belzile et al., 2002; Hargreaves, 2003). The spectroscopic characterization of CDOM is a useful approach in the assessment of the source and quality of DOM (Helms et al., 2008) and quantification of

\footnotetext{
* Corresponding author at: CAS Key Laboratory of Coastal Zone Environmental Processes and Ecological Remediation, Yantai Institute of Coastal Zone Research, Chinese Academy of Sciences, Yantai, Shandong 264003, China.

E-mail address: xlgao@yic.ac.cn (X. Gao).
} 
autochthonous production of DOM (Miller et al., 2009).

As an important fraction of CDOM, the fluorescent DOM (FDOM) can be used for the estimation of the CDOM levels in marine waters. Some investigators have found linear relationships between fluorescence and absorption of CDOM (Ferrari, 2000; Chen et al., 2002; Del Vecchio and Blough, 2004). Fluorescence excitation-emission matrices coupled with parallel factor analysis (EEMs-PARAFAC) has been widely used to study variability of DOM in coastal areas (Stedmon and Markager, 2005a), observe effects of production and degradation processes on DOM fluorescence in marine environments (Mcknight et al., 2001; Stedmon and Markager, 2005b; Huguet et al., 2009; Birdwell and Engel, 2010), and trace anthropogenic pollutants in marine DOM (Murphy et al., 2006). Two primary fluorescing groups in DOM have been identified, i.e. humic-like FDOM and protein-like FDOM (Coble, 2007), and their optical properties and distributions are mainly affected by source, rate of production, transformation and removal mechanisms (Zhou et al., 2016; Xu et al., 2018; Xu and Guo, 2017, 2018).

In coastal waters, river discharge is generally the main source of humic-like FDOM, although it is also produced through in situ microbial activity (Romera-Castillo et al., 2011). The humic-like FDOM has been found to increase in degradation studies (Stedmon and Markager, 2005b; Shimotori et al., 2009; Romera-Castillo et al., 2011) and vary with apparent oxygen utilization (AOU), especially in the Pacific and Southern oceans (Yamashita et al., 2007; Jørgensen et al., 2011). In contrast, protein-like FDOM is known to be from biological production and anthropogenic sources (Baker and Spencer, 2004). Terrestrial humic substances behave conservatively in coastal areas due to their refractory characteristics (Del Castillo et al., 2000), whereas protein substances behave non-conservatively in many estuaries due to their relatively rapid production and degradation (Vignudelli et al., 2004). Coagulation and precipitation within estuaries is an effective pathway for the removal of high molecular weight humic substances (Pempkowiak, 1988). Bacterial uptake is considered as an important sink of CDOM; however, studies indicate that it is an indirect process. Photochemical processes could make CDOM more microbial available (Moran et al., 2000).

The Yellow Sea (YS) is a semi-enclosed shallow sea of the northwestern Pacific bordered by the Bohai Sea in the west, which has offshore characteristics. No large river discharges directly into the YS. The north coast of the Shandong Peninsula, located in the North Yellow Sea (NYS), with a history of over 60 years of marine raft culture (mainly including scallop, mussel and seaweed) in the coastal waters, is one of the fastest developing areas in China. Millions of people live along the north coast of the Shandong Peninsula. Over the last two decades, due to the rapid economic and industrial development in this region, copious amounts of organic and inorganic pollutants have been discharged into its coastal waters. It is estimated that approximately 150 tons of phosphorus and 1910 tons of nitrogen are released into the coastal areas near Yantai City through sewage discharge every year (Han and Liu, 2014), resulting in serious environmental issues, which could affect the DOM concentration, composition, and reactivity in seawaters. For example, hypoxia in the bottom water occurs in summer in the coastal waters of the northern Shandong Peninsula, and algae blooms frequently appear from spring to autumn (Zhai et al., 2014). The information about the temporal-spatial variability of DOM in the coastal waters of the northern Shandong Peninsula has been scarcely documented. Thus, the main objectives of this study were to (1) examine the composition and spatiotemporal variations of DOM, (2) seek the sources of DOM, and (3) reveal the processes that control the origins of DOM in this coastal area.

\section{Materials and methods}

\subsection{Study area and sampling locations}

The research area, which lies in the coastal waters of the northern

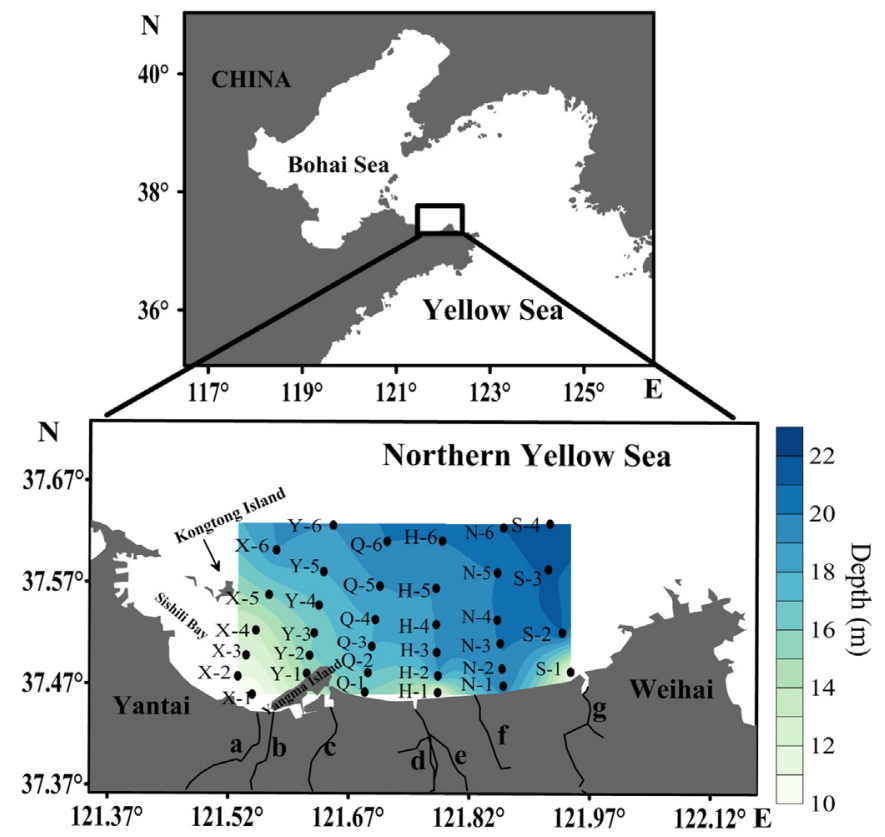

Fig. 1. Sampling sites in the coastal waters of northern Shandong Peninsula. a, b, c, d, e, f and g represent the Xin'an River, Yuniao River, Qinshui River, Han River, Guang River, Nian River and Yangting River, respectively.

Shandong Peninsula along the Yantai-Weihai shoreline (Fig. 1), is one of the intensively maricultured areas in China for the species with important economic significance such as bivalves and sea cucumbers. The maximum depth in this area is about $22 \mathrm{~m}$. The area is dominated by regular semi-diurnal tides; currents flow from the east to the west at flood tides and reverse at ebb tides (Jia et al., 2007), and climatic variations are primarily dominated by the East Asian Monsoon (Chen, 2009). Several small seasonal rivers (i.e. the Xin'an River, Yuniao River, Qinshui River, Han River, Guang River, Nian River and Yangting River) are running along the coastline, which could affect the coastal ecosystem, especially in the rainy season. Meteorological conditions exhibit a pronounced seasonal cycle, which determines strong variations in seawater temperature, salinity and water column stratification during the year. The annual thermal stratification occurs from late spring to late summer and is enhanced by the relatively high sea surface temperature and freshwater advection. From autumn, the water column is mostly homogeneous due to surface cooling and frequent mixing. The rain-bearing southeast monsoon lasts from June to September, while the strong northwest monsoon prevails in winter from November to March of the next year. Algae bloom frequently occurs from spring to autumn (Zhai et al., 2014).

The field data and samples used in this study were obtained through four cruises which were conducted in June, July, August and September 2017, respectively. Water samples were collected at 34 grid stations with a Niskin sampler for the measurement of dissolved organic carbon (DOC) and absorption and fluorescence spectroscopy of CDOM. Two layers of water samples were obtained, i.e. surface $(1 \mathrm{~m}$ under the sea surface) and bottom ( $1 \mathrm{~m}$ above the seabed) waters. Immediately after collection, a subsample $(\sim 40 \mathrm{ml})$ was filtered through pre-acid-cleaned and pre-combusted $\left(500{ }^{\circ} \mathrm{C}\right.$ for $\left.5 \mathrm{~h}\right), 0.7 \mu \mathrm{m}$ pore size Whatman GF/F filters and transferred into clean borosilicate glass bottles (pre-combusted at $500{ }^{\circ} \mathrm{C}$ for $5 \mathrm{~h}$ ) with $1 \%$ saturated $\mathrm{HgCl}_{2}$ solution for DOC analyses. Another subsample $(\sim 50 \mathrm{ml})$ was filtered through acid-rinsed $0.2 \mu \mathrm{m}$ Millipore polycarbonate filters and transferred into $50 \mathrm{ml} \mathrm{HDPE}$ plastic bottles for the analysis of CDOM optical properties. All samples were stored in the dark at $4{ }^{\circ} \mathrm{C}$ before had been analyzed within a few days. 


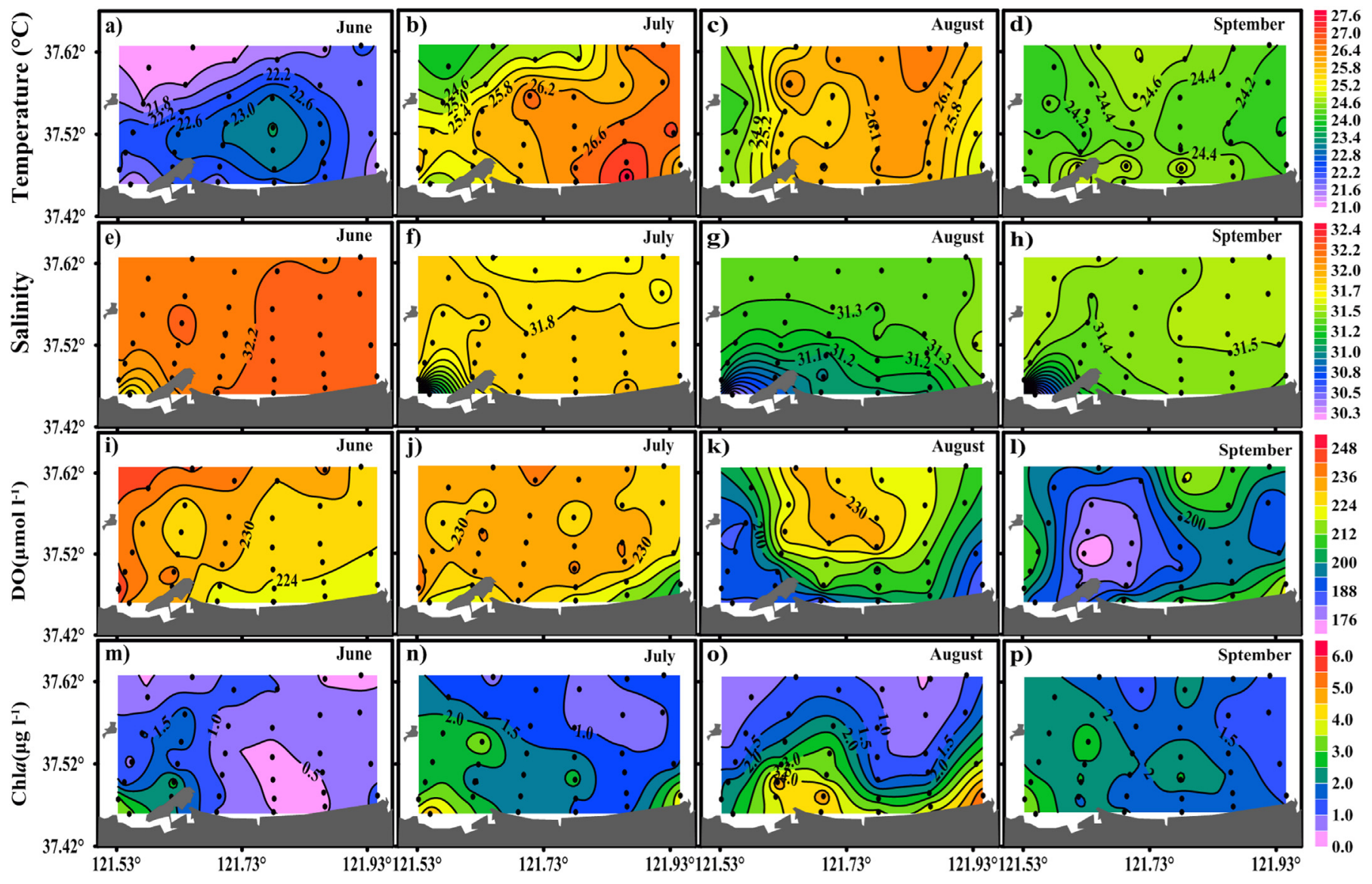

Fig. 2. Spatial distribution of temperature, salinity, DO and Chl $a$ in the surface water from June to September 2017.

\subsection{Analytical methods}

\subsubsection{Hydrographic data}

Hydrographic data, including water temperature, salinity, dissolved oxygen (DO) and chlorophyll $a(\mathrm{Chl} a$ ) were continuously determined using a CTD (Seabird) and a YSI sensors, with the precision being $\pm 0.05{ }^{\circ} \mathrm{C}$ (temperature), \pm 0.01 (salinity), $\pm 0.01 \mathrm{mgl}^{-1}$ (DO) and $\pm 0.01 \mu \mathrm{gl}^{-1}$ (Chl $a$ ). The apparent oxygen utilization (AOU; $\mu \mathrm{mol}$ $\mathrm{I}^{-1}$ ) was calculated as the difference between the saturated oxygen concentration and the observed oxygen concentration (AOU $=\mathrm{O}_{2 \text { sat }}-$ $\mathrm{O}_{2 \text { obs }}$ ), providing an approximation to the balance between biological processes of primary production and respiration (Benson and Krause, 1984).

\subsubsection{Measurements of $D O C$}

The DOC samples were acidified with $\mathrm{H}_{3} \mathrm{PO}_{4}$ to $\mathrm{pH} \leq 2$ to remove the dissolved inorganic carbon and then analyzed using a TOC analyzer (TOC- $\mathrm{V}_{\mathrm{CPH}}$, Shimadzu, Japan) calibrated with potassium biphthalate. The system was checked at intervals of seven consecutive sample analyses against a certified reference material according to GSB07-19672005 made by Institute for Environmental Reference Materials of Ministry of Environmental Protection, China, and the coefficient of variation on five replicate injections was $<2 \%$.

\subsubsection{Absorption and fluorescence spectroscopy}

Samples for spectroscopic analysis were warmed to room temperature $\left(25^{\circ} \mathrm{C}\right)$. CDOM absorbance was measured using a UV-VIS spectrophotometer (TU-1810, PGENERAL) with $10 \mathrm{~cm}$ quartz cuvettes between 200 and 800 at $1 \mathrm{~nm}$ intervals. All sample spectra were blank corrected and referenced against pre-filtered $(0.2 \mu \mathrm{m})$ ultra-pure deionized water $(18.2 \mathrm{M} \Omega-\mathrm{cm})$. Absorbance measurements at each wavelength $(\lambda)$ were baseline corrected by subtracting the mean absorbance calculated in the spectral range from 680 to $700 \mathrm{~nm}$. Absorption coefficients of CDOM $\left(a_{\lambda}\right)$ were calculated based on the following equation:

$a_{\lambda}=2.303 A(\lambda) / l$ where $A(\lambda)$ is the corrected spectrophotometer absorbance reading at wavelength $\lambda$ on the spectrophotometer and $l$ is the cuvette path length $(0.1 \mathrm{~m})$. The spectral slopes for the intervals of $275-295 \mathrm{~nm}\left(S_{275-295}\right)$ was calculated using linear regression of the logtransformed $a_{\lambda}$ spectra, which is expressed as follows:

$a_{\lambda}=a_{\lambda_{0}} \exp \left[-S\left(\lambda_{0}-\lambda\right)\right]+K$

where $a_{\lambda}$ and $a_{\lambda 0}$ are the absorbance values measured at defined wavelength $\lambda$ and at reference wavelength $\lambda_{O}=375 \mathrm{~nm}$, respectively (Helms et al., 2008). The spectral slope (S) describes the approximate exponential decline in absorption with increasing wavelength and $K$ represents the baseline shifts or attenuation due to factors other than CDOM. $S_{275-295}$ can provide information on DOM molecular weight with the lower values indicating the greater proportions of higher molecular weight material (Blough and Del Vecchio, 2002; Helms et al., 2008). Besides, the values of $S_{275-295}$ can also be used as an indicator of terrestrial-origin CDOM (Granskog et al., 2007), or newly-produced CDOM (Nelson et al., 2004), and the low values of which have been linked with terrestrial-origin CDOM. Specific UV absorbance at $254 \mathrm{~nm}$ $\left(\mathrm{SUVA}_{254}\right)$ was calculated as the absorbance value at $254 \mathrm{~nm}$ normalizing to the corresponding DOC concentration. It can be used as a surrogate for aromaticity (Weishaar et al., 2003). The higher values of SUVA $_{254}$ indicate the greater percent of aromaticity.

Excitation emission matrix (EEM) fluorescence properties were determined on a Hitachi F-7000 fluorescence spectrometer (Hitachi HighTechnologies, Tokyo, Japan) equipped with a 700-voltage xenon lamp at a scanning speed of $2400 \mathrm{~nm} \mathrm{~min}^{-1}$. The scanning ranges were 


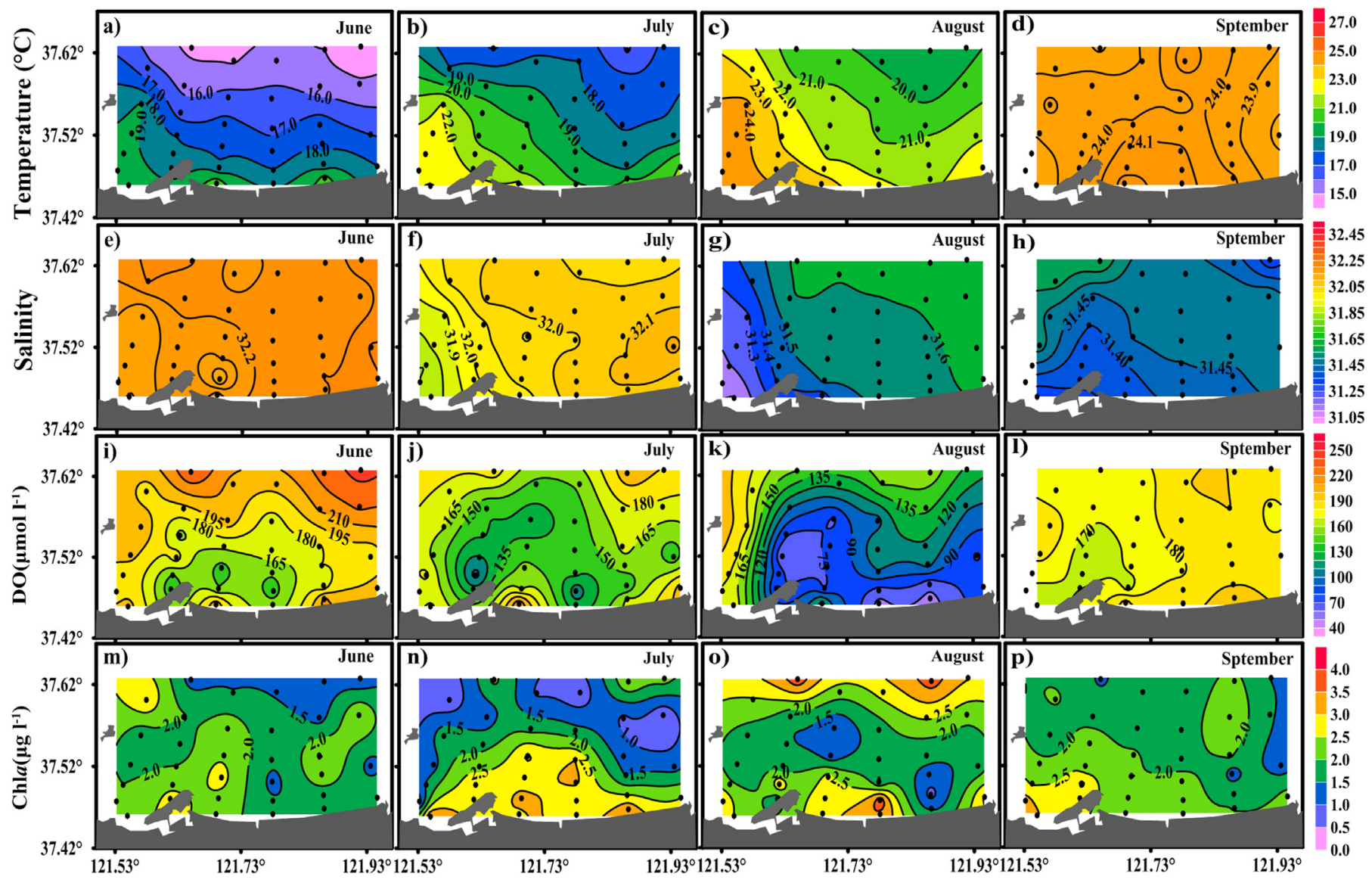

Fig. 3. Spatial distribution of temperature, salinity, DO and Chl $a$ in the bottom water from June to September 2017.

200-600 nm for excitation and emission. Readings were collected in ratio mode at $5 \mathrm{~nm}$ intervals for excitation and at $2 \mathrm{~nm}$ intervals for emission. The band-passes were $5 \mathrm{~nm}$ for both excitation and emission. The inner-filter effect was corrected following the tutorial by Murphy et al. (2011). A pre-filtered $(0.2 \mu \mathrm{m})$ ultra-pure de-ionized water blank EEM fluorescence was subtracted from that of sample EEM to eliminate water Raman scatter peaks (Mcknight et al., 2001; Stedmon et al., 2003), and EEMs were converted to Raman units (RU) using the integrated area under the ultra-pure de-ionized water Raman scatter peak at excitation $350 \mathrm{~nm}$ (Lawaetz and Stedmon, 2009).

The fluorescence index (FIX) was estimated as the ratio of the fluorescence intensity at $450-500 \mathrm{~nm}$ on emission (at $370 \mathrm{~nm}$ on excitation) (Mcknight et al., 2001). It can provide a metric for distinguishing DOM derived from terrestrial and microbial sources, with higher values ( $\sim 1.9$ or higher) indicating microbial-derived material and lower values $(\sim 1.4$ or less) relating to terrestrial DOM sources (Mcknight et al., 2001).

The humification index (HIX) was calculated as the ratio of the area below intensity peak between 434 and $480 \mathrm{~nm}$ on emission (at $255 \mathrm{~nm}$ on excitation) to the area below intensity peak between 300 and $346 \mathrm{~nm}$ on emission (at $255 \mathrm{~nm}$ on excitation) (Zsolnay et al., 1999). The HIX, an indicator of the degree of DOM humification (Ohno, 2002), has lower values $(<4)$ for non-humified DOM of biological or aquatic bacterial origin, but higher values ( $>10$ ) for DOM with a strong humic characteristic or an important terrigenous contribution (Huguet et al., 2009).

The biological index (BIX) was calculated as the ratio of the fluorescence intensity at $380 \mathrm{~nm}$ on emission (at $310 \mathrm{~nm}$ on excitation) to fluorescence intensity at $430 \mathrm{~nm}$ on emission (at $310 \mathrm{~nm}$ on excitation) (Huguet et al., 2009). It indicates the contribution of autochthonous or freshly-produced DOM. High values of BIX $(>1)$ correspond to a predominantly autochthonous origin of DOM, whereas values below 0.6 are considered to contain little autochthonous DOM.

\subsubsection{Parallel factor analysis (PARAFAC) modeling and statistical analyses}

In the parallel factor (PARAFAC) analysis, components that represent individual fluorophores from the large dataset of three-dimensional EEM spectra were extracted, which was carried out in MATLAB R2008a with the DOM Fluor Toolbox (Stedmon and Bro, 2008). Fluorescence intensity of each component was expressed as an $F_{\max }$ in Raman units (RU), which was calculated by multiplying the fluorescence concentration score in every sample EEM with the excitation and emission maxima for each component.

Statistical analyses were performed with the Microsoft Excel 2007. Contour maps were generated by the Surfer 12 (Golden Software LLC) using the kriging method. Pearson's correlation analysis was performed with SPSS 19.0 software to examine the relationships among CDOM related parameters.

\section{Results}

\subsection{Hydrological features}

Complex hydrographic conditions occurred during the study period ( Figs. 2 and 3 and Table 1), which may influence the transport and concentration of biogenic elements. Overall, water salinity was relatively stable (30.3-32.3), while the temperature ranged broadly from 14.3 to $27.6{ }^{\circ} \mathrm{C}$. As for DO, the mean values ranged from $194.2 \pm 12.5$ (mean \pm SD) to $230.4 \pm 7.2 \mu \mathrm{mol} \mathrm{l}^{-1}$ in the surface water and $110.1 \pm 42.4-188.1 \pm 28.1 \mu \mathrm{mol} \mathrm{l}^{-1}$ in the bottom water. During the summer months, the DO values in the bottom water gradually 


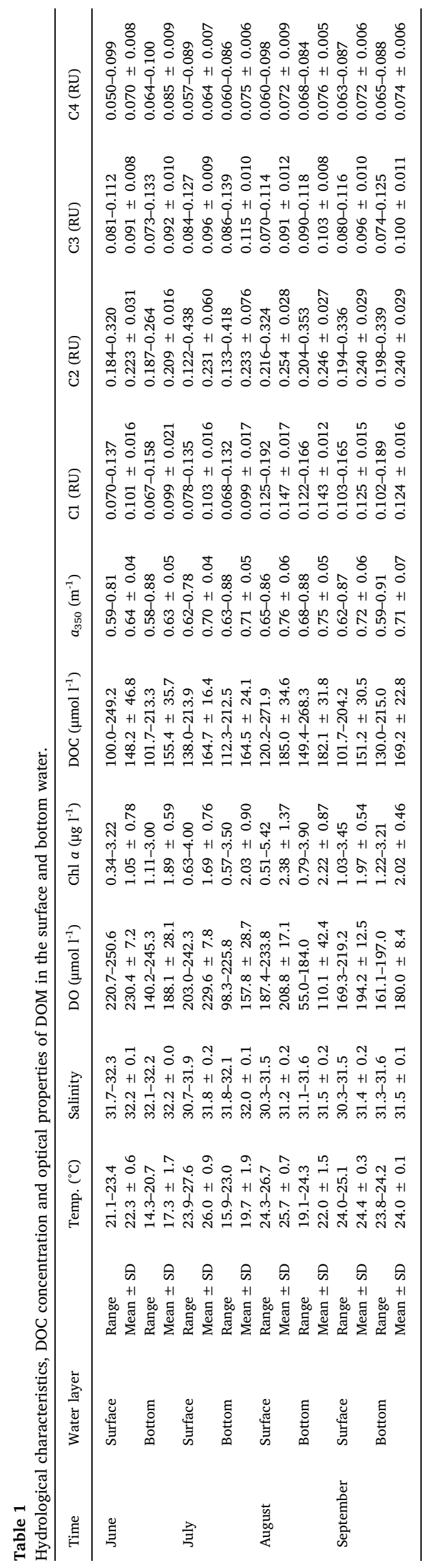

decreased from June, and an apparent hypoxia zone (DO $<62.5 \mu \mathrm{mol} \mathrm{l}^{-}$ ${ }^{1}$ ) (Vaquer-Sunyer and Duarte, 2008) developed in August with the lowest value of $55.0 \mu \mathrm{mol} \mathrm{l}^{-1}$. This was likely related to the increase in the demand for oxygen for the sediment and the degradation of DOM in the water column (Klump et al., 2009). However, the hypoxia phenomenon disappeared in September with the mean DO value of $180.0 \pm 8.4 \mu \mathrm{mol} \mathrm{l}^{-1}$. As an indication of primary production levels, Chl $a$ data ranged from $1.05 \pm 0.78-2.38 \pm 1.37 \mu \mathrm{g} \mathrm{l}^{-1}$ in the surface water and $1.89 \pm 0.59-2.22 \pm 0.87 \mu g l^{-1}$ in the bottom water.

Spatially, the temperature in the surface water was higher in inshore part than offshore part from June to July, while it was contrary to this in August and September (Fig. 2a to d). Surface distribution of salinity (Fig. 2e to h), as a tracer of river water input due to its conservative mixing behavior, highlighted significant differences in hydrology from June to September. The relatively low salinity values mainly distributed at the inshore sampling stations. Especially in August (Fig. 2g) and September (Fig. 2h), this phenomenon was particularly evident, which was related to the water discharge from the Xin'an River. Contrary to the salinity distribution, the Chl $a$ values in the surface water decreased from the river mouth to the offshore area, indicating the effects of river input on flourishing of phytoplankton (Yamashita et al., 2008). The DO values increased from the inshore area to the offshore area from June to August (Fig. 2i to k), but reversed in September (Fig. 21).

In the bottom water, the spatial distributions of water-quality parameters were different from those in the surface water. Overall, the spatial variation in temperature and salinity exhibited an obvious gradient from the inshore zone to the offshore zone (Fig. 3a to h). As for DO (Fig. 3i to 1), the low values were mainly found in the inshore zone. In June (Fig. 3i), the low DO region was initially formed in the area around the Yangma Island, and the minimum value was recorded at the site Y-1 with the value of $140.2 \mu \mathrm{mol} \mathrm{l}^{-1}$. From July to August (Fig. 3j and $\mathrm{k}$ ), the low DO region gradually expanded with the lowest value of $55.0 \mu \mathrm{mol} \mathrm{l}^{-1}$ being recorded. By September (Fig. 31), the hypoxia phenomenon basically disappeared; only a part around the Yangma Island had the low DO values with a minimum of $161.1 \mu \mathrm{mol} \mathrm{l}^{-1}$. It is worth noting that, in August, the relatively high Chl $a$ values (Fig. 20) in the surface water were identified in the low DO region (Fig. 3k) in the bottom water, which provided a clue of DO consumption from OM degradation during an algal bloom decline.

\subsection{Variations of DOC and CDOM characteristics}

\subsubsection{DOC and CDOM absorption properties}

The concentrations of DOC ranged from 100.0 to $271.9 \mu \mathrm{mol} \mathrm{l}^{-1}$ (Table 1). The highest and lowest values were found in the surface water in August $\left(185.0 \pm 34.6 \mu \mathrm{mol} \mathrm{l}^{-1}\right)$ and in June $\left(148.2 \pm 46.8 \mu \mathrm{moll}^{-1}\right)$, respectively. In comparison, the mean DOC value in this study was higher than those found in most of the coastal waters listed in Table 3 (e.g. Amon et al., 2003; Santinelli et al., 2010, 2013; Lechtenfeld et al., 2014; Liu et al., 2014; Sun et al., 2014; Kim et al., 2015; Yang et al., 2016), but lower than that in the Green Bay (Devilbiss et al., 2016). The high DOC may be attributed to the high productivity in the study area along with the riverine input (Li et al., 2013). The horizontal distributions of DOC are displayed in Figs. 5 and 6. In June (Figs. 5a and 6a), a strong DOC gradient appeared in the offshore areas with the high values being recorded at the outermost parts of the study area. From July to August (Figs. 5b, 5c, 6b and 6c), the DOC values decreased from the inshore areas near the Yangma Island to the southeast offshore areas, and the highest value was found at site X-1 near the Xin'an River mouth in August.

As an indicator of CDOM concentration (Hong et al., 2005; Li et al., 2014), the values of $a_{350}$ ranged from 0.58 to $0.91 \mathrm{~m}^{-1}$ (Table 1), which were lower than those found in the Bohai Bay (Li et al., 2014), but higher than those found in the East China Sea (Zhou et al., 2018). Similar to DOC, the highest $a_{350}$ values were also found in August $\left(\sim 0.75 \mathrm{~m}^{-1}\right)$ (Table 1$)$. As for spatial variations of $a_{350}$ (Figs. 5 and 6), 

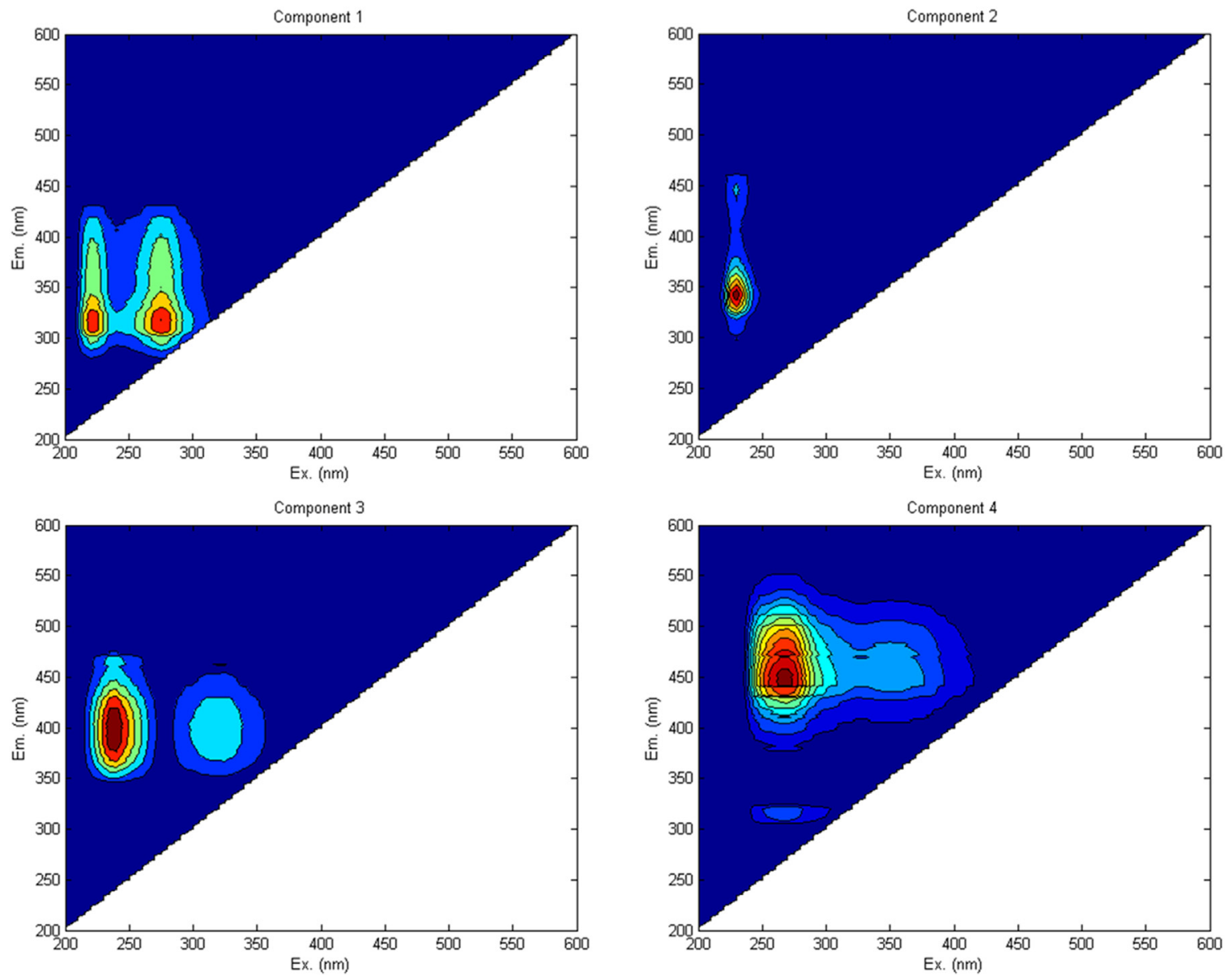

Fig. 4. Excitation-emission matrix spectra contour of the four fluorescent components identified by PARAFAC.

overall, those values were higher in the inshore part than the offshore part with the highest value appearing near the Xin'an River mouth (site $\mathrm{X}-1$ ), which was consistent with the Chl $a$ distribution but contrary to the salinity distribution.

\subsubsection{Fluorescence properties}

Four fluorescent components of DOM (C1-C4) were identified by EEMs-PARAFAC (Fig. 4). The components C1 (Ex/Em = 225, 275/ $320 \mathrm{~nm})$ and $\mathrm{C} 2(\mathrm{Ex} / \mathrm{Em}=235 / 340,450 \mathrm{~nm})$ were similar to tyrosinelike and tryptophan-like components that can be observed in both marine waters (Coble et al., 1998; Murphy et al., 2008; Kowalczuk et al., 2009) and terrestrial waters (Yao et al., 2011), which was associated with biological production and microorganism activity (Borisover et al., 2009; Lu et al., 2009; Xu et al., 2013). Components C3 $(\mathrm{Ex} / \mathrm{Em}=240,325 / 395 \mathrm{~nm})$ and $\mathrm{C} 4(\mathrm{Ex} / \mathrm{Em}=275,325 / 450 \mathrm{~nm})$ were confirmed as humic-like components (Yamashita et al., 2008; Kowalczuk et al., 2013). Component C3 was similar to the marine selfgenerated component observed by Cory and Mcknight (2005) in a closed bay. Coble et al. (1998) also discovered this peak in the open waters of the Maine Bay, and believed that it was related to the production of phytoplankton. Stedmon and Markager (2005b) also found similar fluorescent component C3 in agricultural drainage in Denmark and considered it was related to human production activities. Component C4 appears to be ubiquitous in near-shore coastal waters, estuaries, eutrophic lakes and wastewater (Fellman et al., 2011; Murphy et al., 2011; Osburn et al., 2011; Yamashita et al., 2011); its origin is uncertain but was theorized to be microbial processing of terrestrial DOM, yet a common theme among all of these water types is nutrient enrichment and eutrophication (Stedmon and Markager, 2005b).

Figs. 5 and 6 and Table 1 summarize the fluorescent intensity $\left(F_{\max }\right)$ of FDOM in the present study. The $F_{\max }$ values of components C1-C4 were 0.067-0.192 RU, 0.122-0.438 RU, 0.070-0.139 RU and 0.050-0.100 RU, respectively. The high values of protein-like components (C1and C2) appeared in August, which were in agreement with the various characteristics of $\mathrm{Chl} a$ (Table 1), indicating the increasing importance of in situ produced protein-like FDOM as summer progresses. However, the variations of humic-like components (C3 and C4) were not significantly different from June to September (Table 1). As for the spatial distributions of the C1-C4 components (Figs. 5 and 6), their high values were found in the inshore areas, which was consistent with the distribution of the $a_{350}$.

\subsubsection{Spectral and fluorescent indices}

The spectral indices of absorption $\left(S_{275-295}\right.$ and SUVA $\left._{254}\right)$ and fluorescence (HIX, FIX and BIX) are summarized in Table 2. For all the data set, the $S_{275-295}$ values ranged from 0.017 to $0.034 \mathrm{~nm}^{-1}$, and the low values appeared in July with the mean value being $0.025 \pm 0.002 \mathrm{~nm}^{-1}$ and $0.025 \pm 0.001 \mathrm{~nm}^{-1}$ in the surface and bottom water, respectively, manifesting the higher molecular weight of DOM or more terrestrial-origin DOM appearing in July. They were comparable to those found in the East Taiwan Strait (Yang et al., 2016), but higher than those in the Canadian shelf of the Beaufort Sea (Kim et al., 2015) and lower than those in the East China Sea shelf and the waters off eastern Taiwan (Zhou et al., 2018). The SUVA 254 values

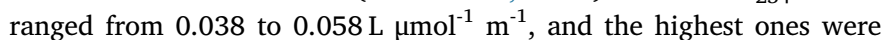
found in July and August. They were comparable to those found in the Martinique Beach (Mathilde et al., 2016), and higher than those in the Green Bay (Devilbiss et al., 2016).

The ranges of FIX, BIX and HIX, which were 1.92-2.74, 1.02-1.91 and $0.85-1.84$ respectively, indicated predominantly autochthonous 


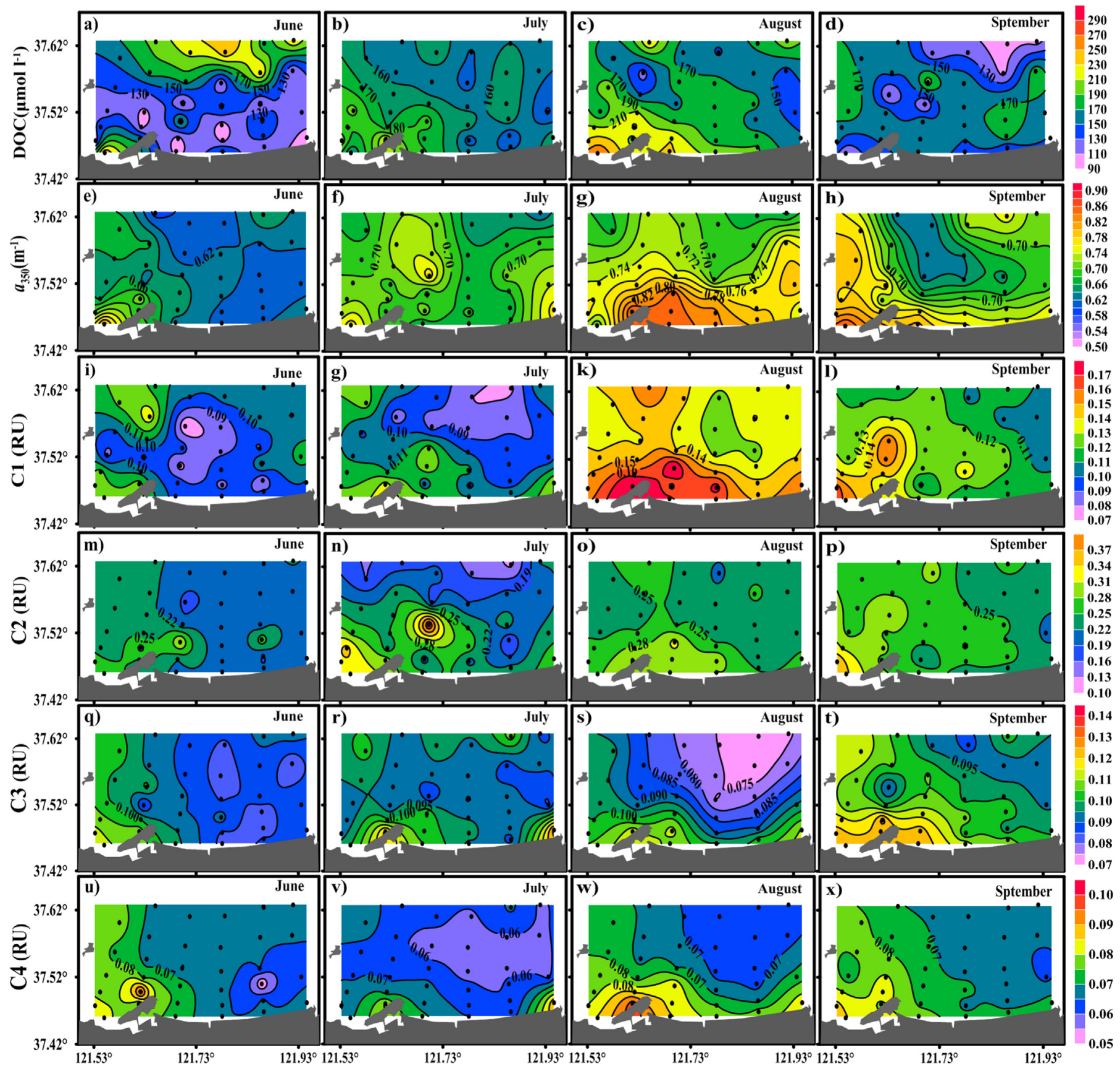

Fig. 5. Spatial distribution of DOC, $a_{350}$ and PARAFAC-derived fluorescent DOM components in the surface water from June to September 2017.

and microbial sources of DOM (Birdwell and Engel, 2010). In comparison, the FIX values in this study were higher than those found in all of the coastal waters listed in Table 3. The BIX values were comparable to those found in the Yangtze Estuary (Sun et al., 2014), but higher than those in the Bohai Bay (Chen and Zheng, 2013), Green Bay (Devilbiss et al., 2016) and Martinique Beach (Mathilde et al., 2016). Contrary to BIX, the HIX values were lower than those in the Bohai Bay (Chen and Zheng, 2013) and Green Bay (Devilbiss et al., 2016), but comparable to those found in the Yangtze Estuary (Sun et al., 2014).

\section{Discussion}

\subsection{Composition and variations of DOM}

From June to September, the DOM parameters (DOC, CDOM and
FDOM) presented obvious monthly variations, which could be driven by the interaction of several factors, e.g. the biological production, the river inputs and the photochemical bleaching. The highest values of DOM appeared in August, while the lowest values were in June (Table 1). Among them, the values of DOC, $a_{350}$ and protein-like components $\mathrm{C} 1$ and $\mathrm{C} 2$ in the surface water in August were on average $24.8 \%, 18.8 \%, 45.5 \%$ and $13.9 \%$ higher than those in June and the corresponding values in the bottom water were $17.2 \%, 19.1 \%, 44.4 \%$ and $17.7 \%$ (Table 1), which showed similar trend with those of Chl $a$ (Table 1), indicating the increase of in situ produced DOM as summer progresses. However, the variations of humic-like components C3 and C4 were not significantly different, suggesting that the factors affecting them did not vary temporally (Table 1 ).

In addition to the concentration of DOM, its composition also changed in different months as can be seen from the plots of $a_{350}$ and 


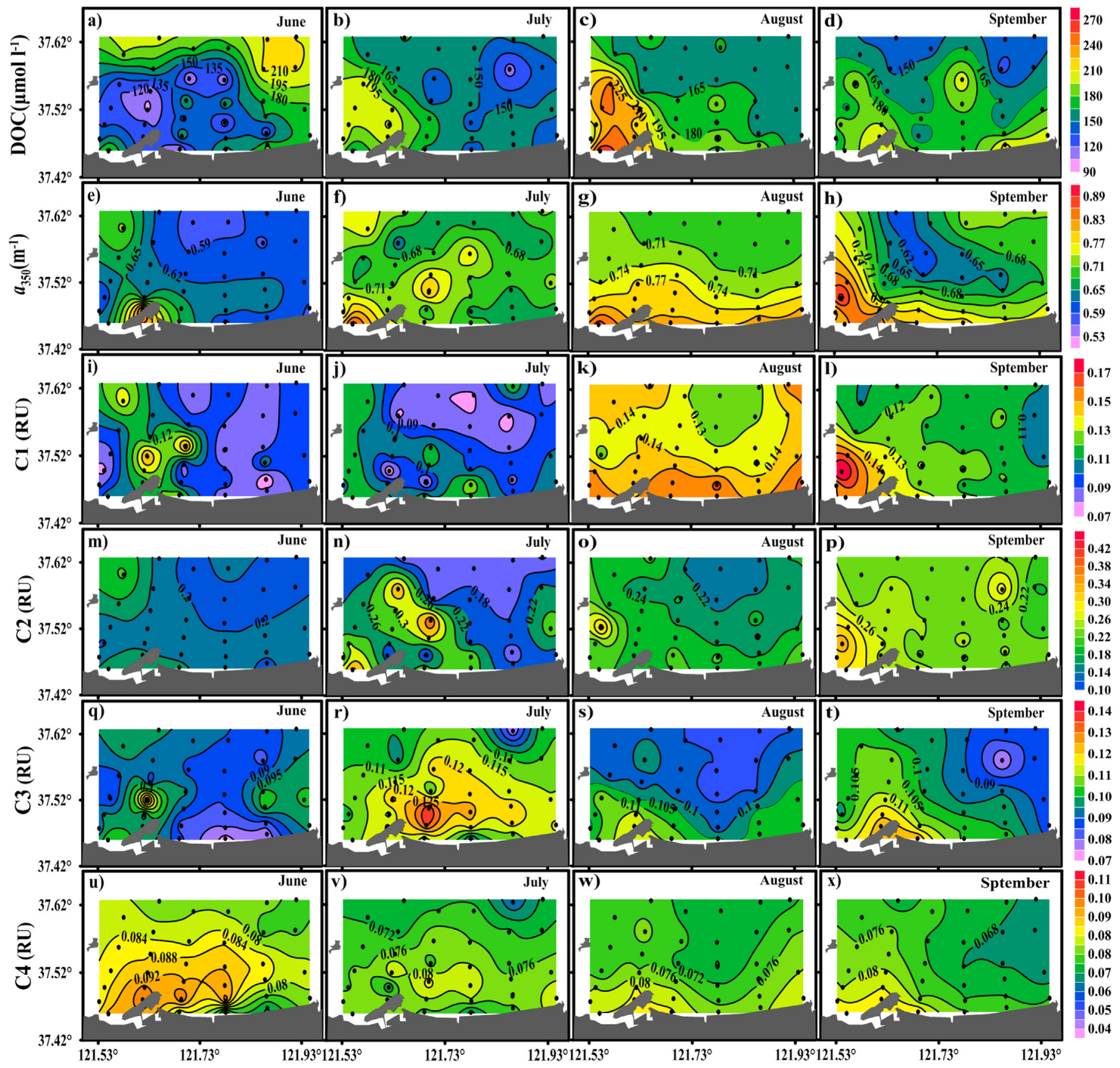

Fig. 6. Spatial distribution of DOC, $a_{350}$ and PARAFAC-derived fluorescent DOM components (RU) in the bottom water from June to September 2017.

DOC vs. the fluorescence data of CDOM (Fig. 7). Several studies demonstrated significant positive correlations between CDOM fluorescence and absorption in various coastal waters (Ferrari, 2000; Chen et al., 2002; Del Vecchio and Blough, 2004), and their coefficients were usually higher than 0.9. Therefore, sometimes, the fluorescence data could be as a more favorable proxy for CDOM spectral observation than absorption, especially in the clear waters with low CDOM concentrations, because fluorescence measurement is much more sensitive than absorption.

In this study, although there were significant positive correlations between $a_{350}$ and total fluorescence intensity $\left(\mathrm{C}_{\mathrm{Tot}}\right)$ which was the sum of the four individual components C1-C4 (Kowalczuk et al., 2010a, $2010 b$ ), their coefficients $\left(R^{2}\right)$ varied from 0.205 to 0.909 (Fig. 7a-d), indicating the variations in the quantum yield of fluorescence, suggestive of the changes in the proportion of CDOM sources (Fellman et al., 2011). The $a_{350}$ had the best linear relationship with $\mathrm{C}_{\mathrm{Tot}}$ in June and August (Fig. 7a and c), while they were less linearly correlated in the other two months in respect of the whole data set of each month. In July, the relatively scattered data (Fig. 7b) were mainly from the sampling stations near the river mouths (sites Y-1, Q-1, H-1, S-2) and the outer edge of the study area (sites Q-5, Y-5, X-6, Y-6, Q-6), indicating the CDOM composition was significantly affected by the river input. In September, the $a_{350}$ and $\mathrm{C}_{\mathrm{Total}}$ data gained from the inshore part of the study area showed a linear relationship of $a_{350}$ $=0.980 \times \mathrm{C}_{\mathrm{Tot}}+0.126\left(\mathrm{R}^{2}=0.703, P<0.001\right)$ in the surface water and $a_{350}=0.867 \times \mathrm{C}_{\mathrm{Tot}}+0.194\left(\mathrm{R}^{2}=0.847, P<0.001\right)$ in the bottom water (Fig. 7d); their data gained from the offshore part of the study area showed a linear relationship of $a_{350}=0.575 \times \mathrm{C}_{\mathrm{Tot}}+0.453$ $\left(\mathrm{R}^{2}=0.672, P<0.001\right)$ in the surface water and $a_{350}=0.895 \times \mathrm{C}_{\mathrm{Tot}}$ $+0.282\left(R^{2}=0.909, P<0.001\right)$ in the bottom water (Fig. $\left.7 d\right)$. Generally, the intercept of the $a_{350}-\mathrm{C}_{\mathrm{Tot}}$ equation could be regarded as the non-fluorescent CDOM values. In this study, the non-fluorescent 
Table 2

The spectral and fluorescent indices in the surface and bottom water.

\begin{tabular}{|c|c|c|c|c|c|c|c|}
\hline Time & Depth & & $\mathrm{S}_{275-295}\left(\mathrm{~nm}^{-1}\right)$ & $\operatorname{SUVA}_{254}\left(\mathrm{~L} \mu \mathrm{mol}^{-1} \mathrm{~m}^{-1}\right)$ & FIX & HIX & BIX \\
\hline \multirow[t]{4}{*}{ June } & Surface & Range & $0.026-0.034$ & $0.042-0.055$ & $1.95-2.74$ & $0.85-1.46$ & $1.07-1.21$ \\
\hline & & Mean \pm SD & $0.028 \pm 0.002$ & $0.046 \pm 0.002$ & $2.13 \pm 0.15$ & $1.21 \pm 0.10$ & $1.14 \pm 0.04$ \\
\hline & Bottom & Range & $0.017-0.029$ & $0.042-0.053$ & $1.92-2.45$ & $1.21-1.84$ & $1.04-1.91$ \\
\hline & & Mean \pm SD & $0.026 \pm 0.002$ & $0.045 \pm 0.002$ & $2.17 \pm 0.12$ & $1.57 \pm 0.16$ & $1.12 \pm 0.14$ \\
\hline \multirow[t]{4}{*}{ July } & Surface & Range & $0.020-0.029$ & $0.044-0.058$ & $1.93-2.73$ & $0.86-1.70$ & $1.03-1.24$ \\
\hline & & Mean \pm SD & $0.025 \pm 0.002$ & $0.048 \pm 0.003$ & $2.13 \pm 0.15$ & $1.16 \pm 0.15$ & $1.12 \pm 0.06$ \\
\hline & Bottom & Range & $0.023-0.029$ & $0.043-0.058$ & $1.96-2.35$ & $1.09-1.77$ & $1.02-1.19$ \\
\hline & & Mean \pm SD & $0.025 \pm 0.001$ & $0.047 \pm 0.003$ & $2.12 \pm 0.10$ & $1.44 \pm 0.20$ & $1.11 \pm 0.04$ \\
\hline \multirow[t]{4}{*}{ August } & Surface & Range & $0.022-0.029$ & $0.043-0.055$ & $1.99-2.47$ & $0.89-1.57$ & $1.10-1.24$ \\
\hline & & Mean \pm SD & $0.027 \pm 0.001$ & $0.048 \pm 0.003$ & $2.16 \pm 0.13$ & $1.32 \pm 0.14$ & $1.17 \pm 0.04$ \\
\hline & Bottom & Range & $0.025-0.029$ & $0.040-0.050$ & $2.00-2.37$ & $1.38-1.69$ & $1.07-1.25$ \\
\hline & & Mean \pm SD & $0.026 \pm 0.001$ & $0.046 \pm 0.003$ & $2.18 \pm 0.10$ & $1.53 \pm 0.07$ & $1.15 \pm 0.04$ \\
\hline \multirow[t]{4}{*}{ September } & Surface & Range & $0.026-0.034$ & $0.043-0.054$ & $1.99-2.68$ & $0.92-1.65$ & $1.10-1.33$ \\
\hline & & Mean \pm SD & $0.028 \pm 0.002$ & $0.047 \pm 0.003$ & $2.18 \pm 0.13$ & $1.40 \pm 0.16$ & $1.18 \pm 0.05$ \\
\hline & Bottom & Range & $0.025-0.030$ & $0.038-0.051$ & $1.99-2.41$ & $1.11-1.69$ & $1.07-1.28$ \\
\hline & & Mean \pm SD & $0.028 \pm 0.001$ & $0.044 \pm 0.003$ & $2.15 \pm 0.10$ & $1.46 \pm 0.13$ & $1.17 \pm 0.05$ \\
\hline
\end{tabular}

CDOM average accounted for $64.1 \%, 84.8 \%$ and $42.4 \%$ of the CDOM in the surface water and $61.4 \%, 83.0 \%$ and $43.6 \%$ of the CDOM in the bottom water from June to August. In September, the non-fluorescent CDOM in the surface water on average accounted for $17.5 \%$ of the CDOM in the nearshore zone and $62.9 \%$ in the offshore zone, and the corresponding values in the bottom water were $27.3 \%$ and $39.7 \%$ respectively.

The relationship between fluorescence components and DOC, which has been studied in many coastal areas (e.g. Del Vecchio and Blough, 2004; Mannino et al., 2008) with some empirical relationships between CDOM optical properties and DOC concentrations being presented (e.g. Vodacek et al., 1995; Ferrari et al., 1996), was also analyzed for the further understanding of the compositional changes of DOM. In this study, the CDOM fluorescence had a significant linear relationship with DOC only in July (Fig. 7f) and August (Fig. 7g). This could be explained by the photochemical and biological mediated alteration of the DOM consumption and production (Del Vecchio and Blough, 2004; Mannino et al., 2008). By calculation based on the $\mathrm{C}_{\mathrm{Tot}}$ and DOC regression equation, the values of non-fluorescence DOC (when the $\mathrm{C}_{\mathrm{Tot}}=0$ ) were about $86.13 \mu \mathrm{mol} \mathrm{l}^{-1}$ in the surface water in July, and 30.94 and 30.13 $\mu \mathrm{mol} \mathrm{l}^{-1}$ in the surface and bottom waters in August, respectively, which were consistent with the previous reports of $10-80 \mu \mathrm{mol} \mathrm{l}^{-1}$ in coastal waters and estuarine areas (Rochelle-Newall and Fisher, 2002a; Mannino et al., 2008).

\subsection{Evaluation of DOM sources from spectral and fluorescent indices}

The values of $S_{275-295}$ decreased from June to July, and then increased, while the monthly variations of $\mathrm{SUVA}_{254}$ were opposite to those of the $S_{275-295}$ (Table 2). Those changes indicated that a large amount of with high molecular weight and aromatic structures were produced during the early stage of summer, and the following decrease in these CDOM components could be attributed to the microbial activity. As for fluorescent indices, the low and variable values of HIX and the high constant values of BIX (Table 2) suggested predominantly autochthonous and microbial sources of DOM.

Spatially, Chl $a$ had a significant positive correlation with SUVA $_{254}$ and FIX, but a negative correlation with $S_{275-295}$ and BIX (Table 4), indicating that the components with higher molecular weight and more aromatic structures could be derived from phytoplankton. In addition, the salinity vs. spectral and fluorescent indices also showed significant correlations (Table 4), while those correlations were opposite to those of Chl $a$, suggesting the river input also has a significant impact on DOM dynamics (Yang et al., 2015). The correlations between AOU vs. spectral and fluorescent indices varied from month to month (Table 4). For example, in June and August, the AOU was negatively correlated with $S_{275-295}$ and positively correlated with BIX (Table 4); however, it was opposite in September (Table 4). Those results indicated the effects of microbial activity on DOM varied in different months (Hayase and Shinozuka, 1995).

\subsection{Factors of driving variations of DOM in different months}

There were obvious concentration gradients in the data of fluorescent component, $a_{350}$ and DOC during the investigated period, being higher around the Yangma Island and lower in the offshore patches (Figs. 5 and 6). Three possible explanations may account for this distribution characteristic. First, the river input itself is an important source of DOM, especially in August and September (Fig. $2 \mathrm{~g}$ and h). Second, nutrient inputs from the runoff that support high productivity in this area potentially support a higher biological production of DOM. Finally, the sources from the microbial activities (Chen and Bada, 1992; Hayase and Shinozuka, 1995) yield an increase in DOM.

\subsubsection{Phytoplankton production}

Phytoplankton has previously been shown to be an important source of CDOM in the field studies and laboratory algal culture experiments (Yamashita and Tanoue, 2004; Hanamachi et al., 2008; Zhang et al., 2009). Etheridge and Roesler (2004) observed that CDOM increased markedly at the height of the bloom during a brown tide. RochelleNewall and Fisher (2002b) suggested that phytoplankton was not a direct source of CDOM supporting the idea that CDOM production results from bacterial degradation of DOM deriving from algal cells.

In agreement with these previous studies, phytoplankton blooms is likely to act as an important source of CDOM in this study area. In the field investigations from June to September, the monthly mean value of $a_{350}$ in the surface water increased from $0.64 \pm 0.04 \mathrm{~m}^{-1}$ in June to $0.76 \pm 0.06 \mathrm{~m}^{-1}$ in August, and then decreased to $0.72 \pm 0.06 \mathrm{~m}^{-1}$ in September, which accompanied the increase of Chl a concentration from $1.05 \pm 0.78 \mu \mathrm{gl}^{-1}$ to $2.38 \pm 1.37 \mu \mathrm{gl}^{-1}$ and decreased to $1.97 \pm 0.54 \mu \mathrm{gl}^{-1}$, respectively (Table 1 ), reflecting the synchronous trend for variation in Chl $a$ and CDOM. Spatially, significant linear relationships between $a_{350}$ and $\mathrm{Chl} a$ in the surface water were observed during June to August $(P<0.01)$ (Fig. 8; Table S1), indicating that phytoplankton was the primary source of $\mathrm{CDOM}$ in those months. Based on the difference between the intercept of the $a_{350}$ - Chl $a$ equation and the monthly mean value of $a_{350}$, the contribution of phytoplankton to CDOM from June to August was estimated to be 11.6-35.2\%.

In order to further analyze which fluorophores were produced by the phytoplankton, the regression analyses between the four fluorescent components C1-C4 and Chl $a$ were carried out (Fig. 8; Table S1). From June to September, all the components C1-C4 had a significant linear relationship with Chl $a$ in the surface water (Fig. 8; Table S1), indicating phytoplankton was an important source of protein-like 


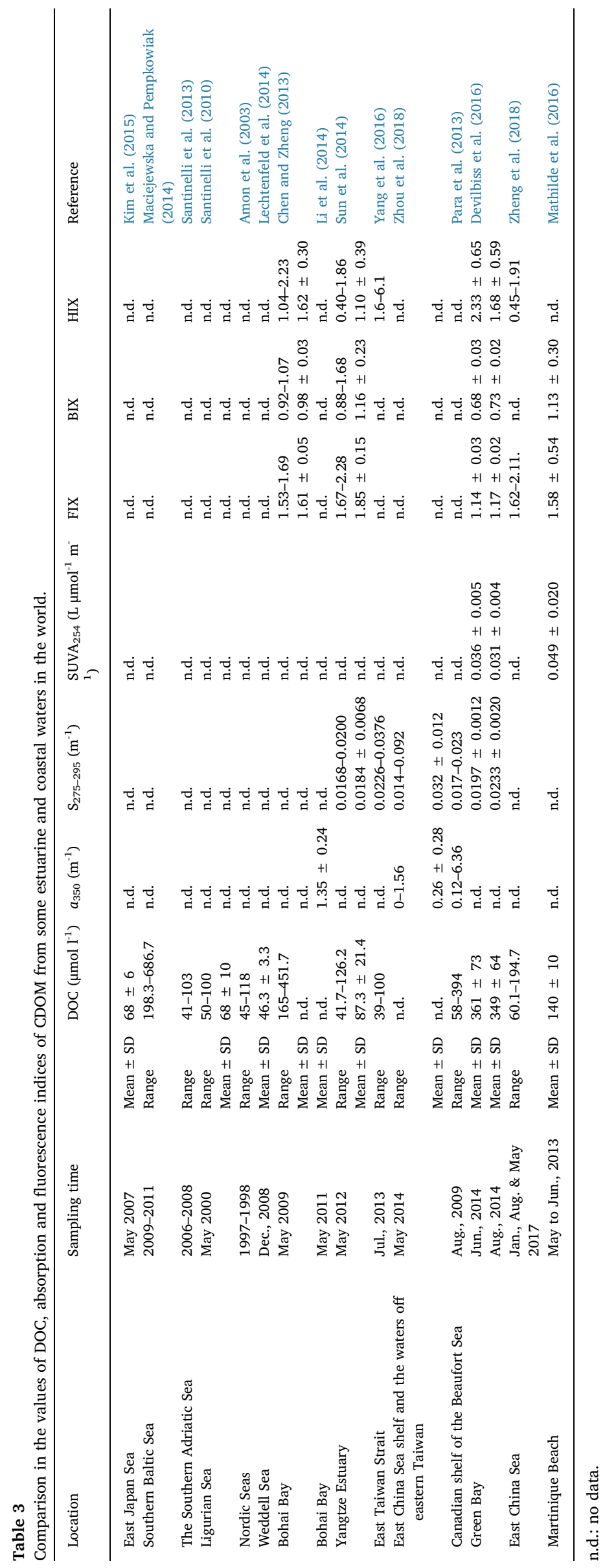



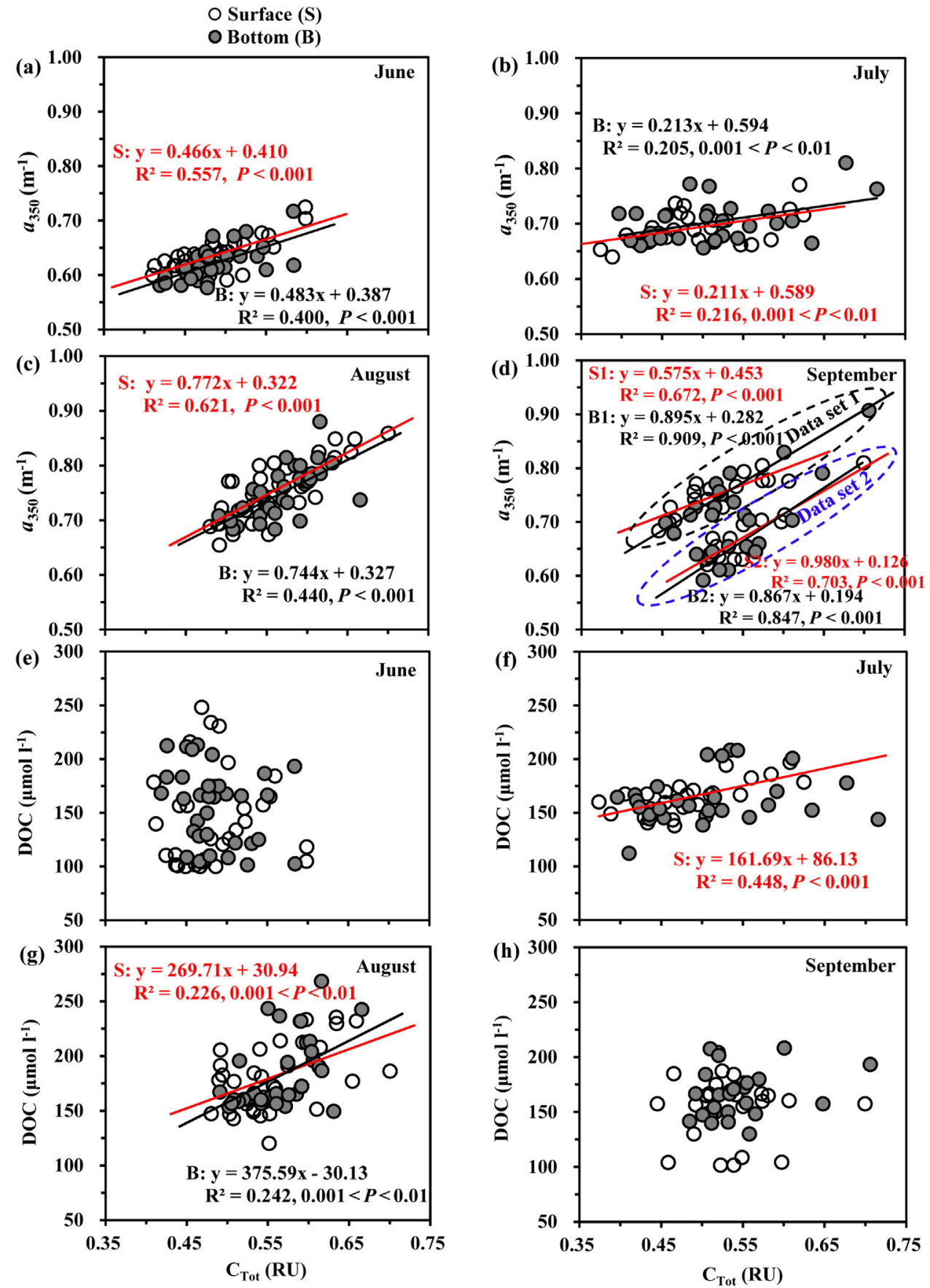

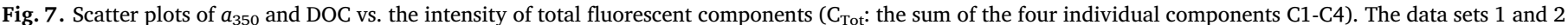
grouped by the black and blue dotted ellipses in panel d were gained from the offshore and inshore parts of the study area, respectively.

components $\mathrm{C} 1$ and $\mathrm{C} 2$ and humic-like components C3 and C4, which was consistent with the previous research of phytoplankton in culture experiments (Norrman et al., 1995; Determann et al., 1998). Xu et al. (2013) reported that the fluorescence intensity of tryptophan-like substances was positively related to the cell number of Microcystis aeruginosa, indicating that there existed a high amount of tryptophanlike substances in extracellular polymeric substances matrix of Microcystis aggregation. McIntyre and Guéguen (2013) found that humic-like peak C (Ex/Em 320-360/420-460 nm) was associated with microbial degradation of algal material whereas humic-like peak M (Ex/Em 290$310 / 370-410 \mathrm{~nm}$ ) was associated with algal production. The slope values of the FDOM C1-C4 - Chl $a$ equations were 0.009-0.024 for C1 vs. Chl $a, 0.011-0.052$ for C2 vs. Chl $a, 0.006-0.008$ for C3 vs. Chl $a$ and
0.005-0.008 for C4 vs. Chl $a$, respectively (Table S1). Overall, the lowest slope values of the aforementioned equations were all observed in August indicating the net FDOM C1-C4 produced by unit phytoplankton was relatively low. This could be attributed to the high photochemical bleaching of FDOM and phytoplankton degradation due to microbial activities (Zhang et al., 2011) in summer. The contribution of phytoplankton to different fluorescence components was estimated based on the components C1-C4 - Chl a regression equations (Table S1). The results indicated that, from June to September, $9.0-37.4 \%$ and $9.1-37.4 \%$ of the protein-like components $\mathrm{C} 1$ and C2 were newly produced by phytoplankton, while for the humic-like components $\mathrm{C} 3$ and C4 the corresponding values were $7.8-18.7 \%$ and $11.4-19.9 \%$, respectively. 
Table 4

Correlation between spectral and fluorescence indices and salinity, Chl $a$ and AOU.

\begin{tabular}{|c|c|c|c|c|c|c|c|}
\hline Parameters & Time & Water layer & $S_{275-295}$ & SUVA $_{254}$ & FIX & BIX & HIX \\
\hline \multirow[t]{4}{*}{ Chl $a$} & June & $\begin{array}{l}\text { Surface } \\
\text { Bottom }\end{array}$ & $-0.740^{c}$ & $0.779^{c}$ & $0.559^{c}$ & & \\
\hline & July & $\begin{array}{l}\text { Surface } \\
\text { Bottom }\end{array}$ & $-0.538^{c}$ & $0.672^{\mathrm{c}}$ & $0.532^{\mathrm{b}}$ & $-0.458^{b}$ & \\
\hline & August & $\begin{array}{l}\text { Surface } \\
\text { Bottom }\end{array}$ & $-0.529^{b}$ & $0.658^{c}$ & & & \\
\hline & September & $\begin{array}{l}\text { Surface } \\
\text { Bottom }\end{array}$ & & $0.379^{\mathrm{a}}$ & $\begin{array}{l}0.344^{\mathrm{a}} \\
0.413^{\mathrm{a}}\end{array}$ & $-0.600^{c}$ & \\
\hline \multirow[t]{4}{*}{ Salinity } & June & $\begin{array}{l}\text { Surface } \\
\text { Bottom }\end{array}$ & $0.802^{c}$ & $-0.699^{c}$ & $-0.686^{c}$ & & \\
\hline & July & $\begin{array}{l}\text { Surface } \\
\text { Bottom }\end{array}$ & $0.598^{c}$ & $-0.599^{c}$ & $\begin{array}{l}-0.664^{\mathrm{c}} \\
0.343^{\mathrm{a}}\end{array}$ & $0.500^{\mathrm{b}}$ & $-0.357^{\mathrm{a}}$ \\
\hline & August & $\begin{array}{l}\text { Surface } \\
\text { Bottom }\end{array}$ & $0.791^{c}$ & $\begin{array}{l}-0.756^{\mathrm{c}} \\
-0.341^{\mathrm{a}}\end{array}$ & $-0.455^{b}$ & & $\begin{array}{l}-0.368^{\mathrm{a}} \\
-0.446^{\mathrm{b}}\end{array}$ \\
\hline & September & $\begin{array}{l}\text { Surface } \\
\text { Bottom }\end{array}$ & & & $-0.737^{c}$ & $0.603^{\mathrm{c}}$ & $-0.383^{\mathrm{a}}$ \\
\hline \multirow[t]{4}{*}{$\mathrm{AOU}$} & June & $\begin{array}{l}\text { Surface } \\
\text { Bottom }\end{array}$ & $-0.388^{\mathrm{a}}$ & $0.474^{\mathrm{b}}$ & & $0.604^{c}$ & \\
\hline & July & Surface & & & $0.437^{\mathrm{a}}$ & & \\
\hline & August & $\begin{array}{l}\text { Bottom } \\
\text { Surface } \\
\text { Bottom }\end{array}$ & $\begin{array}{l}-0.531^{\mathrm{b}} \\
-0.439^{\mathrm{a}}\end{array}$ & $0.441^{\mathrm{a}}$ & & $\begin{array}{l}0.411^{\mathrm{a}} \\
0.396^{\mathrm{a}}\end{array}$ & \\
\hline & September & $\begin{array}{l}\text { Surface } \\
\text { Bottom }\end{array}$ & $\begin{array}{l}0.613^{c} \\
0.561^{c}\end{array}$ & $0.504^{b}$ & & $-0.419^{\mathrm{a}}$ & \\
\hline
\end{tabular}

Only the values with $P<0.05$ were shown.

a $0.01<P<0.05$.

b $0.001<P<0.01$.

c $P<0.001$.

As for DOC, it had a significant linear relationship with Chl $a$ in the surface water in July $\left(\mathrm{R}^{2}=0.493, P<0.001\right)$ and August $\left(\mathrm{R}^{2}=\right.$ $0.119, P<0.05$ ) (Fig. 8b; Table S1). By calculation based on the difference between the monthly concentration of DOC and the intercept of DOC - Chl $a$ regression equation, the contributions of Chl $a$ to DOC accounted for $12.3 \%$ in July and $10.8 \%$ in August. However, no significant linear relationship between DOC and Chl $a$ was found in June and September suggesting the sources of DOC in these two months were more complicated.

\subsubsection{River/sewage inputs}

River/sewage inputs can play a significant role in DOM dynamics in coastal waters (Yang et al., 2015; Wang et al., 2018). In the study area, there are two important cities along the coastline, i.e. Yantai and Weihai. Over the last two decades, due to the rapid economic and industrial development, large amounts of sewage have been discharged into the study area of this research. Hao et al. (2011) reported that Yantai's discharge of municipal sewage into the Sishili Bay, which locates in the western part of this study area, increased from $1.13 \times 10^{8}$ tons in 2002-1.44 $\times 10^{8}$ tons in 2007. The discharge of municipal sewage into the Weihai Bay (near the east part of this study area) was about $3.64 \times 10^{7}$ tons in 2007 (Gong, 2008). This sewage has an important influence on the concentration and composition of DOM. On one hand, it can carry some of terrestrial DOM into coastal waters; on the other hand, nutrient inputs from the sewage that support high primary productivity could potentially provide a higher biological production of DOM. During the investigation, the water salinity (Table 1) in August (mean $31.2 \pm 0.2$ ) and September (mean $31.4 \pm 0.2$ ) was lower than that in June (mean $32.2 \pm 0.1$ ) and July (mean $31.8 \pm 0.2$ ). Spatially, salinity showed a significant gradient distribution in August (Fig. 2g) and September (Fig. 2h) indicating the obvious river inputs in these two months.

The scatter plots of DOC, $a_{350}$ and fluorescent components C1-C4 vs. salinity are shown in Fig. 9 for the better understanding of the relationships between DOM parameters and river inputs. There was a significant negative linear relationship between DOC and salinity in
August (Fig. 9b; Table S2, $P<0.001$ ) and a predominance source of terrestrial DOM came from the Xin'an River, where the lowest salinity was observed (Figs. $2 \mathrm{~g}$ and $5 \mathrm{c}$ ). That was because an important sewage treatment plant is located near the mouth of the Xin'an River. Since 2003, most residential and industrial sewage from the Laishan District of Yantai has been treated by the sewage treatment plant, and the discharge of sewage into the sea every day increased from $2 \times 10^{4}$ tons in 2003-9 $\times 10^{4}$ tons in 2010 (Xing et al., 2013). In August and September, the rainy season, a large amount of terrestrial material was discharged into the sea with abundant precipitation via the Xin'an River (Xing et al., 2013), which increased the DOM concentration. Meanwhile, nutrients carried by riverine inputs promoted the reproduction of phytoplankton. Employing the salinity-DOC regression equation, the freshwater end members for DOC in August were estimated to be 3750 $\mu \mathrm{mol} \mathrm{l}^{-1}$ in the surface water and $5281 \mu \mathrm{mol}^{-1}$ in the bottom water. In comparison, those values are much higher than the discharge mean DOC concentration in the major rivers in other seas, e.g. the Baltic Sea $\left(621.3 \mu \mathrm{moll}^{-1}\right)$ (Bianchi et al., 1997) and the Sabine-Neches Estuary $\left(841 \mu \mathrm{moll}^{-1}\right)$ (Kowalczuk et al., 2010a, 2010b), which can be explained by two aspects. First of all, the freshwater end members for DOC could be magnified in a highly productive coastal system due to nutrient inputs. In particular, the presence of higher production, respectively were restricted close to shore seem to have a strong influence on DOC without affecting salinity. In addition, the DOC variability over a small salinity range $(30-32)$ may cause some bias in the regression parameters.

In addition, the regression analysis of salinity vs. $a_{350}$ showed that the river discharge was a main driving force that governed CDOM variability in June, August and September (Fig. 9a; Table S2). The $a_{350}$ had a significant negative relationship with salinity in June $\left(\mathrm{R}^{2}=\right.$ $0.261, P<0.01)$, August $\left(\mathrm{R}^{2}=0.583, P<0.001\right)$ and September $\left(\mathrm{R}^{2}\right.$ $=0.259, P<0.01)$ in the surface water and in August $\left(\mathrm{R}^{2}=0.267\right.$, $P<0.01$ ) in the bottom water (Fig. 9a; Table S2). The $a_{350}$ range for the freshwater end member was $5.6-11.74 \mathrm{~m}^{-1}$. In comparison, the $a_{350}$ was more significantly correlated to salinity (Fig. 9a; Table S2) than Chl $a$ (Fig. 8a; Table S1) in August and September suggesting that, in 

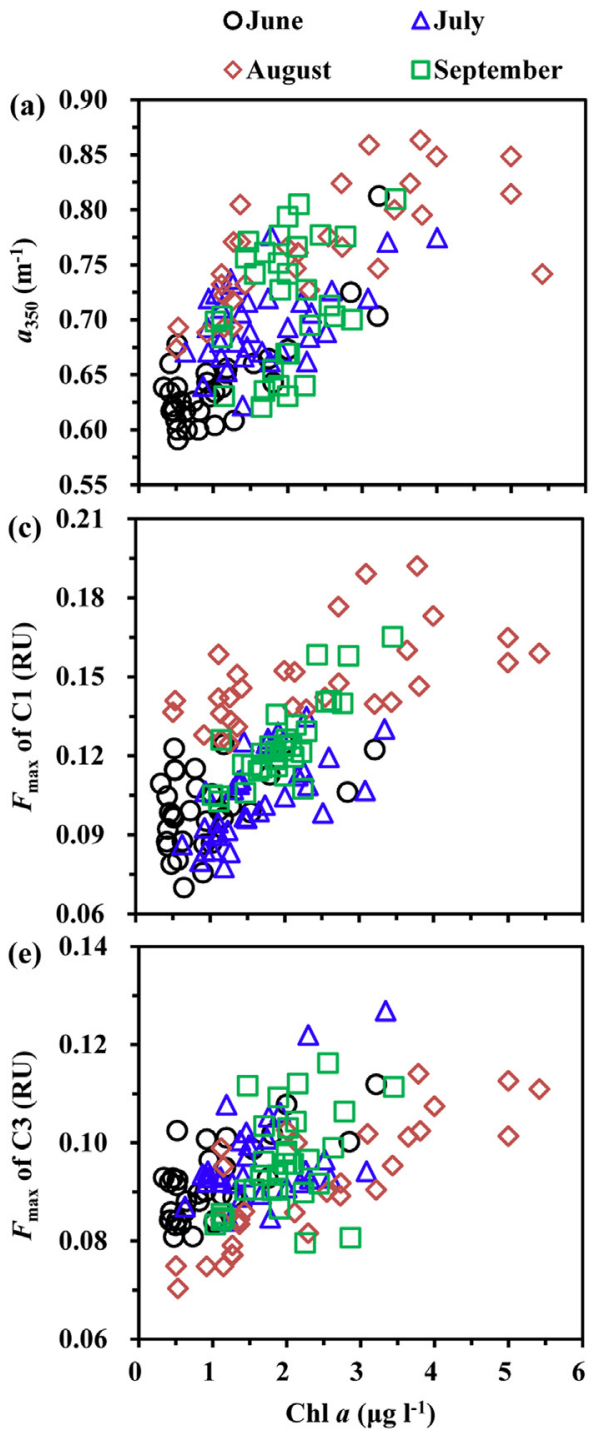
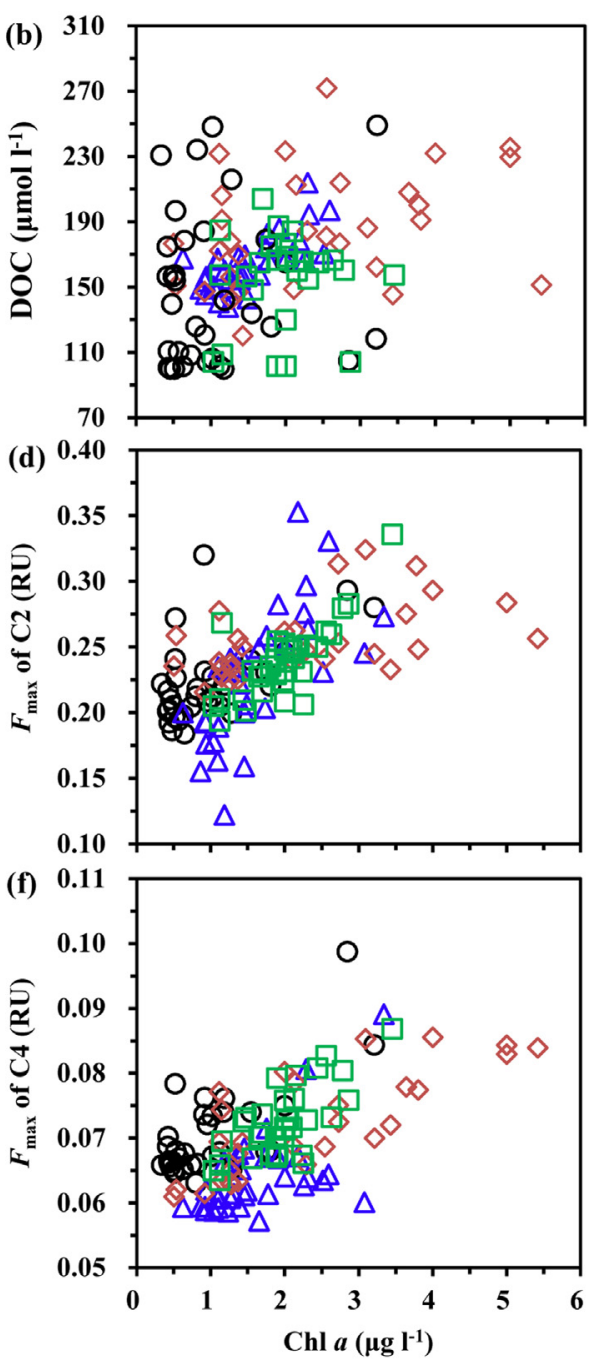

Fig. 8. Scatter plots of $a_{350}$, DOC and the intensity of fluorescent components C1-C4 vs. Chl $a$ in the surface water.

addition to the reproduction of phytoplankton, the input of terrestrial organic matter also had important effects on CDOM dynamics. In contrast, the $a_{350}$ was more significantly correlated to Chl $a$ (Fig. 8a; Table S1) than salinity (Fig. 9a; Table S2) in June and July, indicating the predominant in situ CDOM sources of phytoplankton.

As for FDOM, the four fluorescent components C1-C4 had significant negative linear relationships with salinity in August and September (Fig. 9c-f; Table S2). During the investigation, the proteinlike components C1 and C2 in August and humic-like component C3 in September were more significantly correlated to salinity (Fig. 9c-e; Table S2) than that of Chl $a$ (Fig. 8c-e; Table S1), suggesting that there was obvious terrestrial input of protein-like FDOM in August and humic-like FDOM in September. In addition, the remaining components were more significantly correlated to Chl $a$ (Fig. 8c-f; Table S1) than that of salinity (Fig. 9c-f; Table S2) from June to September, indicating that phytoplankton was the primary source of those FDOM constituents. It was because that the water body in this study area was in oligotrophic status (unpublished data in our study), which also been proved in previous research (Xing et al., 2013). Thus, the nutrient input from river/sewage greatly promoted the reproduction of phytoplankton as can be seen from the reverse spatial distribution of salinity and Chl $a$, and then affected the DOM dynamics.

\subsubsection{Production/transformation of DOM by microbial activity}

Microbial activity has been shown to play a significant role in DOM production and transformation in coastal waters (Raymond and Bauer, 2001). Microbial communities can transform the non-chromophoric compounds to fluorescent material (Rochelle-Newall and Fisher, 2002b). In addition, extra DOM can be produced along with degradation of OM by microbial respiration in bottom water (Chen and Bada, 1992; Hayase and Shinozuka, 1995). In this study, the DOC values in the bottom water were on average $4.86 \%,-0.12 \%,-1.57 \%$ and $11.9 \%$ higher than those in the surface water from June to September (Table 1), while the $a_{350}$ values in the surface and bottom waters had only minor differences $(<2 \%)$. As for FDOM, the $F_{\max }$ values of humiclike components C3 and C4 in the bottom water were on average $1.1 \%$ and $21.4 \%, 19.8 \%$ and $17.2 \%, 13.2 \%$ and $15.6 \%$, and $4.2 \%$ and $2.8 \%$ higher than those in the surface water from June to September, while the $F_{\max }$ values of protein-like $\mathrm{C} 1$ and $\mathrm{C} 2$ in the bottom water were $0-6 \%$ (mean $4.5 \%$ ) lower than those in the surface water (Table 1). The higher concentrations of humic-like FDOM in the bottom water probably arose from the bacterially mediated microbial aerobic degradation of particulate matter (Guo et al., 2011). In general, AOU in water mass represents the net consumption of oxygen and is a key indicator of aerobic respiration in OM biogeochemistry (Benson and Krause, 1984). A significant relationship between humic-like FDOM (Coble's M-peak) and AOU has been reported by Yamashita and Tanoue (2008) in the 


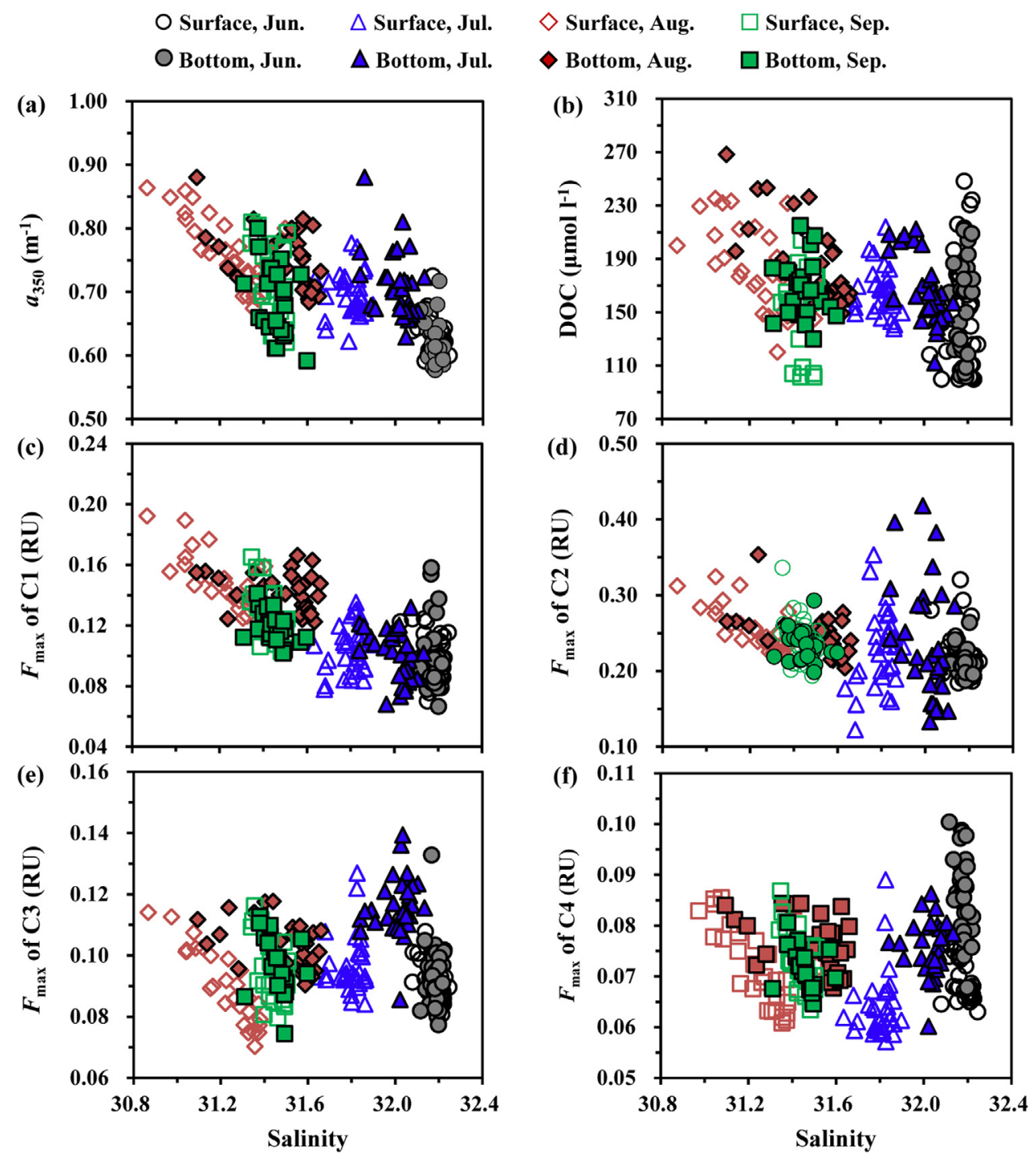

Fig. 9. Scatter plots of $a_{350}$, DOC and the intensity of fluorescent components C1-C4 vs. salinity.

OJune $\Delta$ July $\diamond$ August $\square$ September
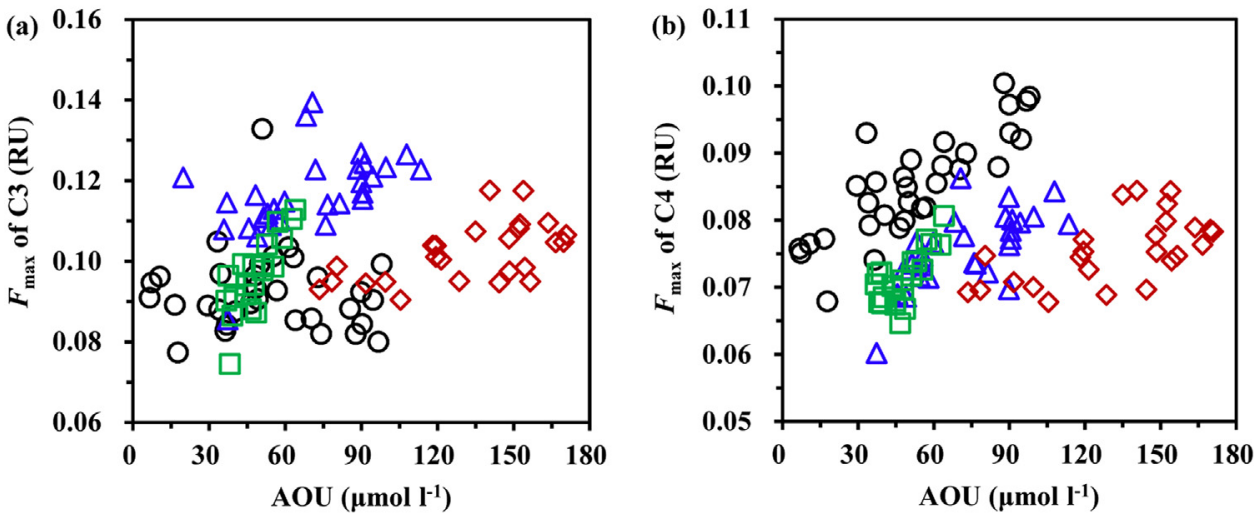

Fig. 10. Scatter plots of the intensity of fluorescent components C3 and C4 vs. AOU in the bottom water.

bottom water of the Pacific Ocean Basin. They found positive and strong linear FDOM-AOU correlations in the mesopelagic layer but with substantial differences in slope and intercept. Such differences were associated with the mixing of source waters with different initial levels of FDOM. In order to evaluate the in situ production rate of FDOM from the respiration rate, Yamashita and Tanoue (2008) considered only the
FDOM-AOU linear relationship in the deep water where one single dominant water mass was found. Taking into account the mixing of waters with different sources in the surface water, only the relationships of DOC, $a_{350}$, fluorescence intensity and AOU in the bottom water were discussed in this research.

As shown in Fig. 10 and Table S3, a significant positive relationship 
between the component C3 and AOU was observed in July $\left(\mathrm{R}^{2}=0.237\right.$, $P<0.01)$, August $\left(\mathrm{R}^{2}=0.315, P<0.001\right)$ and September $\left(\mathrm{R}^{2}=\right.$ $0.668, P<0.001)$ in the bottom water. As for the component $\mathrm{C} 4 \mathrm{vs.}$ AOU, a significant positive relationship between them was found in all the four months with the $\mathrm{R}^{2}$ values of $0.353-0.695(P<0.001)$ in the bottom water. These provide a clue that microbial aerobic degradation of sinking biogenic particles could be an important source of humic-like components (Yamashita and Tanoue, 2008; Jørgensen et al., 2011). It was estimated based on the AOU-components C3 and C4 regression equations in Table S3, in the bottom water of this study area, 9.1\%, $18.7 \%$ and $48.5 \%$ of the C3 in July, August and September and $14.6 \%$, $16.3 \%, 18.0 \%$ and $26.6 \%$ of the C4 from June to September could be attributed to the microbial degradation of OM.

However, AOU had no significant correlation with the protein-like components C1 and C2, DOC and $a_{350}$ in the bottom water. This feature was also reported in some previous literature such as Zeri et al. (2014) and Pitta et al. (2019). This is because organic particulates, mostly phytoplanktonic cells and detritus, could be enzymatically solubilized by bacteria resulting in the release of DOM (Azam et al., 1983), thus distorting the relationships of AOU with DOC, $a_{350}$ and the protein-like components $\mathrm{C} 1$ and $\mathrm{C} 2$.

\section{Conclusions}

This study investigated the spatiotemporal variations in DOM and the main controlling factors in a coastal mariculture region of the northern Shandong Peninsula in summer. From June to September, the values of DOC and CDOM absorption and fluorescence parameters presented significant monthly variations and were highest in August. As for spatial distributions, their values were higher in the inshore patches than the offshore patches, especially in the spot near the Xin'an River mouth. The spectral and fluorescent indices indicated a predominantly autochthonous and microbial source of DOM.

Phytoplankton reproduction, river/sewage inputs and the degradation of organic matter all affected the concentration and composition of DOM. Phytoplankton was the main source of CDOM and FDOM. During the investigation, the proportion of CDOM that was newly produced by phytoplankton on average accounted for $11.6-35.2 \%$; as for the components of FDOM, $9.0-37.4 \%$ of $\mathrm{C} 1,9.1-37.4 \%$ of C2, $7.8-18.7 \%$ of C3 and $11.4-19.9 \%$ of C4 were from newly produced by phytoplankton. In addition, the riverine/sewage inputs, especially from the Xin'an River, had a significant role in DOM dynamics. In the bottom water, microbial aerobic degradation of sinking biogenic particles was also an important source of humic-like components, which contributed to $9.1 \%, 18.7 \%$ and $48.5 \%$ for C3 in July, August and September, and 14.6\%, 16.3\%, $18.0 \%$ and $26.6 \%$ for C4 from June to September.

\section{Acknowledgments}

This work was financially co-supported by the Strategic Priority Research Program of the Chinese Academy of Sciences (XDA23050303) and the Joint Fund of National Natural Science Foundation of China and Shandong Provincial Government (U1606404).

\section{Appendix A. Supplementary material}

Supplementary data associated with this article can be found in the online version at doi:10.1016/j.csr.2019.02.006.

\section{References}

Amon, R.M.W., Budéus, G., Meon, B., 2003. Dissolved organic carbon distribution and origin in the Nordic Seas: exchanges with the Arctic Ocean and the north Atlantic. J. Geophys. Res-Oceans 108 (C7), 14-1-16.

Azam, F., Frenchel, T., Field, J.G., Gray, J.S., Meyer-Reil, L.A., Thingstad, F., 1983. The ecological role of water-column microbes in the sea. Mar. Ecol. Prog. Ser. 10, 257-263.
Baker, A., Spencer, R.G.M., 2004. Characterization of dissolved organic matter from source to sea using fluorescence and absorbance spectroscopy. Sci. Total Environ. 333 (1-3), 217-232.

Belzile, C., Vincent, W.F., Kumagai, M., 2002. Contribution of absorption and scattering to the attenuation of UV and photosynthetically available radiation in Lake Biwa. Limnol. Oceanogr. 47, 95-107.

Benson, B.B., Krause, D., 1984. The concentration and isotopic fractionation of oxygen dissolved in fresh water and seawater in equilibrium with the atmosphere. Limnol. Oceanogr. 29, 620-632.

Bianchi, T.S., Baskaran, M., DeLord, J., Ravichandran, M., 1997. Carbon cycling in a shallow turbid estuary of southeast Texas: the use of plant pigment biomarkers and water quality parameters. Estuaries 20 (2), 404-415.

Birdwell, J.E., Engel, A.S., 2010. Characterization of dissolved organic matter in cave and spring waters using UV-Vis absorbance and fluorescence spectroscopy. Org. Geochem. 41 (3), 270-280.

Blough, N.V., Del Vecchio, R., 2002. Chromophoric DOM in the coastal environment. In: Hansell, D., Carlson, C. (Eds.), Biogeochemistry of Marine Dissolved Organic Matter. Academic Press, New York, pp. 509-546.

Borisover, M., Laor, Y., Parparov, A., Bukhanovsky, N., Lado, M., 2009. Spatial and seasonal patterns of fluorescent organic matter in Lake Kinneret (Sea of Galilee) and its catchment basin. Water Res. 43 (12), 3104-3116.

Carlson, C.A., Hansell, D.A., 2014. DOM sources, sinks, reactivity, and budgets. In: Carlson, C.A., Hansell, D.A. (Eds.), Biogeochemistry of marine dissolved organic matter, 2nd ed. Academic Press, pp. 65-126.

Chen, C.T.A., 2009. Chemical and physical fronts in the Bohai, Yellow and East China seas. J. Mar. Syst. 78, 394-410.

Chen, H., Zheng, B., 2013. Sources of fluorescent dissolved organic matter in high salinity seawater (Bohai Bay, China). Environ. Sci. Pollut. R. 20 (3), 1762-1771.

Chen, R.F., Bada, J.L., 1992. The fluorescence of dissolved organic matter in seawater. Mar. Chem. 37 (3-4), 191-221.

Chen, R.F., Zhang, Y., Vlahos, P., Rudnick, S.M., 2002. The fluorescence of dissolved organic matter in the Mid-Atlantic Bight. Deep Sea Res. Part II Top. Stud. Oceanogr. 49 (20), 4439-4459.

Coble, G., 2007. Marine optical biogeochemistry: the chemistry of ocean color. Chem. Rev. 107 (2), 402-418.

Coble, P.G., DelCastillo, C.E., Avril, B., 1998. Distribution and optical properties of CDOM in the Arabian Sea during the 1995 southwest monsoon. Deep Sea Res. Part II Top. Stud. Oceanogr. 45, 2195-2223.

Cory, R.M., Mcknight, D.M., 2005. Fluorescence spectroscopy reveals ubiquitous presence of oxidized and reduced quinones in dissolved organic matter. Environ. Sci. Technol. 39 (21), 8142-8149.

Del Castillo, C.E., Gilbes, F., Coble, P.G., Muller-Karger, F.E., 2000. On the dispersal of riverine colored dissolved organic matter over the West Florida Shelf. Limnol. Oceanogr. 45 (6), 1425-1432.

Del Vecchio, R., Blough, N.V., 2004. Spatial and seasonal distribution of chromophoric dissolved organic matter and dissolved organic carbon in the Middle Atlantic Bight. Mar. Chem. 89, 169-187.

Determann, S., Lobbes, J.M., Reuter, R., Rullkötter, J., 1998. Ultraviolet fluorescence excitation and emission spectroscopy of marine algae and bacteria. Mar. Chem. 62 (1-2), 137-156.

Devilbiss, S.E., Zhou, Z., Klump, J.V., Guo, L.D., 2016. Spatiotemporal variations in the abundance and composition of bulk and chromophoric dissolved organic matter in seasonally hypoxia-influenced Green Bay, Lake Michigan, USA. Sci. Total Environ. $565,742-757$.

Etheridge, S.M., Roesler, C.S., 2004. Temporal variations in phytoplankton, particulates, and colored dissolved organic material based on optical properties during a Long Island brown tide compared to an adjacent embayment. Harmful Algae 3 (4), 331-342.

Fellman, J.B., Petrone, K.C., Grierson, P.F., 2011. Source, biogeochemical cycling, and fluorescence characteristics of dissolved organic matter in an agro-urban estuary. Limnol. Oceanogr. 56 (1), 243-256.

Ferrari, G.M., 2000. The relationship between chromophoric dissolved organic matter and dissolved organic carbon in the European Atlantic coastal area and in the West Mediterranean Sea (Gulf of Lions). Mar. Chem. 70 (4), 339-357.

Ferrari, G.M., Dowell, M.D., Grossi, S., Targa, C., 1996. Relationship between optical properties of chromophoric dissolved organic matter and total concentration of dissolved organic carbon in southern Baltic Sea region. Mar. Chem. 55, 299-316.

Gong, Y.J., 2008. The Pollutant Dispersion and environmental capacity in Weihai Bay Sea Area (Doctoral dissertation). Ocean University of China.

Granskog, M.A., Macdonald, R.W., Mundy, C.J., Barber, D.G., 2007. Distribution, characteristics and potential impacts of chromophoric dissolved organic matter (CDOM) in the Hudson strait and the Hudson Bay, Canada. Cont. Shelf. Res. 27 (15), 2032-2050.

Guo, W.D., Yang, L.Y., Hong, H.S., 2011. Assessing the dynamics of chromophoric dissolved organic matter in a subtropical estuary using parallel factor analysis. Mar. Chem. 124, 125-133.

Han, Q.Y., Liu, D.Y., 2014. Temporal and spatial variations in the distribution of macroalgal communities along the Yantai Coast, China. Chin. J. Oceanol. Limnol. 32 (3), 595-607.

Hanamachi, Y., Hama, T., Yanai, T., 2008. Decomposition process of organic matter derived from freshwater phytoplankton. Limnology 9 (1), 57-69.

Hansell, D.A., Carlson, C.A., Repeta, D.J., Schlitzer, R., 2009. Dissolved organic matter in the ocean: a controversy stimulates new insights. Oceanography 22 (4), 202-211.

Hao, Y., Tang, D., Yu, L., Xing, Q., 2011. Nutrient and chlorophyll a anomaly in red-tide periods of 2003-2008 in Sishili Bay, China. Chin. J. Oceanol. Limn. 29 (3), 664-673.

Hargreaves, B.R., 2003. Water column optics and penetration of UVR. In: Helbling, E.W., 
Zagarese, H. (Eds.), UV Effects in Aquatic Organisms and Ecosystems 1. The Royal Society of Chemistry, Cambridge UK, pp. 59-108.

Hayase, K., Shinozuka, N., 1995. Vertical distribution of fluorescent organic matter along with AOU and nutrients in the equatorial Central Pacific. Mar. Chem. 48, 283-290.

Helms, J.R., Stubbins, A., Ritchie, J.D., Minor, E.C., Kieber, D.J., Mopper, K., 2008. Absorption spectral slopes and slope ratios as indicators of molecular weight, source, and photobleaching of chromophoric dissolved organic matter. Limnol. Oceanogr. 53 (3), 955-969.

Hong, H.S., Wu, J.Y., Shang, S.L., Hu, C.M., 2005. Absorption and fluorescence of chromophoric dissolved organic matter in the Pearl River Estuary, South China. Mar. Chem. 97, 78-89.

Huguet, A., Vacher, L., Relexans, S., Saubusse, S., Froidefond, J.M., Parlanti, E., 2009. Properties of fluorescent dissolved organic matter in the Gironde Estuary. Org. Geochem. 40 (6), 706-719.

Jia, Y.R., Liu, X.J., Sun, Y.L., Sun, C.Q., 2007. Argumentation of sewage discharge mixing zone's area of Xin'an River Sewage Plant of Yantai. Mar. Sci. Bull. 26, 33-37.

Jiao, N., Herndl, G.J., Hansell, D.A., Benner, R., Kattner, G., Wilhelm, S.W., Kirchman, D.L., Weinbauer, M.G., Luo, T., Chen, F., Azam, F., 2010. Microbial production of recalcitrant dissolved organic matter: long-term carbon storage in the global ocean. Nat. Rev. Micro 8 (8), 593-599.

Jørgensen, L., Stedmon, C.A., Kragh, T., Markager, S., Middelboe, M., Søndergaardv, M., 2011. Global trends in the fluorescence characteristics and distribution of marine dissolved organic matter. Mar. Chem. 126 (1-4), 139-148.

Kim, T.H., Kim, G., Lee, S.A., Dittmar, T., 2015. Extraordinary slow degradation of dissolved organic carbon (DOC) in a cold marginal sea. Sci. Rep. 5, 13808.

Klump, J.V., Fitzgerald, S.A., Waples, J.T., 2009. Benthic biogeochemical cycling, nutrient stoichiometry, and carbon and nitrogen mass balances in a eutrophic freshwater bay. Limnol. Oceanogr. 54, 692-712.

Kowalczuk, P., Cooper, W.J., Durako, M.J., Kahn, A.E., Gonsior, M., Young, H., 2010a. Characterization of dissolved organic matter fluorescence in the South Atlantic bight with use of parafac model: relationships between fluorescence and its components, absorption coefficients and organic carbon concentrations. Mar. Chem. 118 (1-2), 22-36.

Kowalczuk, P., Durako, M.J., Young, H., Kahn, A.E., Cooper, W.J., Gonsior, M., 2009. Characterization of dissolved organic matter fluorescence in the south Atlantic bight with use of parafac model: interannual variability. Mar. Chem. 113 (3-4), 182-196.

Kowalczuk, P., Tilstone, G.H., Zabłocka, M., Rttgers, R., Thomas, R., 2013. Composition of dissolved organic matter along an Atlantic meridional transect from fluorescence spectroscopy and parallel factor analysis. Mar. Chem. 157, 170-184.

Kowalczuk, P., Zablocka, M., Sagan, S., Kulinski, K., 2010b. Fluorescence measured in situ as a proxy of CDOM absorption and DOC concentration in the Baltic Sea. Oceanologia 52 (3), 431-471.

Lawaetz, A.J., Stedmon, C.A., 2009. Fluorescence intensity calibration using the Raman scatter peak of water. Appl. Spectrosc. 63 (8), 936-940.

Lechtenfeld, O.J., Kattner, G., Flerus, R., Mccallister, S.L., Schmitt-Kopplin, P., Koch, B.P., 2014. Molecular transformation and degradation of refractory dissolved organic matter in the Atlantic and southern ocean. Geochim. Cosmochim. Acta 126 (2), 321-337.

Li, H.M., Shi, X.Y., Shang, R.N., Han, X.R., 2013. Distribution of dissolved organic carbon and its influence factors in the Bohai Sea and Yellow Sea in autumn. Mar. Environ. Sci. 32 (2), 161-164.

Li, G.J., Liu, J., Ma, Y.L., Zhao, R.H., Hu, S.Z., Li, Y.J., Wei, H., Xie, H.X., 2014. Distribution and spectral characteristics of chromophoric dissolved organic matter in a coastal Bay in Northern China. J. Environ. Sci. 26 (8), 1585-1595.

Liu, Q., Pan, D., Bai, Y., Wu, K., Chen, C.T.A., Liu, Z., Zhang, L., 2014. Estimating dissolved organic carbon inventories in the East China Sea using remote-sensing data. J. Geophys. Res-Oceans 119 (10), 6557-6574.

Lu, F., Chang, C.H., Lee, D.J., He, P.J., Shao, L.M., Su, A., 2009. Dissolved organic matter with multi-peak fluorophores in landfill leachate. Chemosphere 74 (4), 575-582.

Maciejewska, A., Pempkowiak, J., 2014. DOC and POC in the water column of the Southern Baltic. Part I. Evaluation of factors influencing sources, distribution and concentration dynamics of organic matter. Oceanologia 56 (3), 523-548.

Mannino, A., Russ, M.E., Hooker, S.B., 2008. Algorithm development and validation for satellite-derived distributions of DOC and CDOM in the U.S. middle Atlantic bight. J. Geophys. Res-Oceans 113 (C7), 1-19.

Mathilde, C., Christian, N., Gwénaëlle, C., 2016. Microtidal subterranean estuaries as a source of fresh terrestrial dissolved organic matter to the coastal ocean. Mar. Chem. $186,46-57$.

McIntyre, A.M., Guéguen, C., 2013. Binding interactions of algal-derived dissolved organic matter with metal ions. Chemosphere 90 (2), 620-626.

Mcknight, D.M., Boyer, E.W., Westerhoff, P.K., Doran, P.T., Kulbe, T., Andersen, D.T., 2001. Spectro-fluorometric characterization of dissolved organic matter for indication of precursor organic material and aromaticity. Limnol. Oceanogr. 46 (1), 38-48.

Miller, C., Gordon, K.G., Kieber, R.J., Willey, J.D., Seaton, P.J., 2009. Chemical characteristics of chromophoric dissolved organic matter in rainwater. Atmos. Environ. $43,2497-2502$.

Moran, A.M., Sheldon, W.M., Zepp, R.G., 2000. Carbon loss and optical changes during long-term photochemical and biological degradation of estuarine dissolved organic matter. Limnol. Oceanogr. 45 (6), 1254-1264.

Murphy, K.R., Hambly, A., Singh, S., Henderson, R.K., Baker, A., Stuetz, R., Khan, S.J, 2011. Organic matter fluorescence in municipal water recycling schemes: toward a unified PARAFAC model. Environ. Sci. Technol. 45 (7), 2909-2916.

Murphy, K.R., Ruiz, G.M., Dunsmuir, W.T.M., Waite, T.D., 2006. Optimized parameters for fluorescence-based verification of ballast water exchange by ships. Environ. Sci. Technol. 40, 2357-2362.

Murphy, K.R., Stedmon, C.A., Waite, T.D., Ruiz, G.M., 2008. Distinguishing between terrestrial and autochthonous organic matter sources in marine environments using fluorescence spectroscopy. Mar. Chem. 108 (1-2), 40-58.

Nelson, N.B., Carlson, C.A., Steinberg, D.K., 2004. Production of chromophoric dissolved organic matter by Sargasso Sea microbes. Mar. Chem. 89, 273-287.

Nieke, B., Reuter, R., Heuermann, R., Wang, H., Babin, M., Therriault, J.C., 1997. Light absorption and fluorescence properties of chromophoric dissolved organic matter $(\mathrm{CDOM})$ in the St. Lawrence estuary (Case 2 waters). Cont. Shelf Res. 17 (3), 235-252.

Norrman, B., Zwelfel, U.L., Hopkinson, C.S., Brian, F., 1995. Production and utilization of dissolved organic carbon during an experimental diatom bloom. Limnol. Oceanogr. 40 (5), 898-907.

Ohno, T., 2002. Fluorescence inner-filtering correction for determining the humification index of dissolved organic matter. Environ. Sci. Technol. 36 (4), 742-746.

Osburn, C.L., Wigdahl, C.R., Fritz, S.C., Saros, J.E., 2011. Dissolved organic matter composition and photoreactivity in prairie lakes of the U.S. Great Plains. Limnol. Oceanogr. 56 (6), 2371-2390.

Para, J., Charrière, B., Matsuoka, A., Miller, W.L., 2013. UV/PAR radiations and DOM properties in surface coastal waters of the Canadian shelf of the Beaufort Sea during summer 2009. Biogeosciences 9 (10), 2761-2774.

Pempkowiak, J., 1988. The Distribution, Origin and Properties of Humic Acids in the Baltic Sea. Ossolineum, Wrocław, Poland, pp. 146.

Pitta, E., Zeri, C., Tzortziou, M., Rijkenberg, M.J., 2019. Transformations of dissolved organic matter in the Marmara Sea traced by its optical signature. J. Mar. Syst. 189, $1-11$.

Raymond, P.A., Bauer, J.E., 2001. DOC cycling in a temperate estuary: a mass balance approach using natural ${ }^{14} \mathrm{C}$ and ${ }^{13} \mathrm{C}$ isotopes. Limnol. Oceanogr. 46 (3), 655-667.

Raymond, P.A., Spencer, R.G.M., 2015. Riverine DOM. In: Hansell, D.A., Carlson, C.A (Eds.), Biogeochemistry of Marine Dissolved Organic Matter. Academic Press, London, pp. 509-533.

Rochelle-Newall, E.J., Fisher, T.R., 2002a. Chromophoric dissolved organic matter and dissolved organic carbon in Chesapeake Bay. Mar. Chem. 77 (1), 23-41.

Rochelle-Newall, E.J., Fisher, T.R., 2002b. Production of chromophoric dissolved organic matter fluorescence in marine and estuarine environments: an investigation into the role of phytoplankton. Mar. Chem. 77 (1), 7-21.

Romera-Castillo, C., Sarmento, H., Álvarez-Salgado, X.A., Gasol, J.M., Marrasé, C., 2011. Net production and consumption of fluorescent colored dissolved organic matter by natural bacterial assemblages growing on marine phytoplankton exudates. Appl. Environ. Microbiol. 77 (21), 7490-7498.

Santinelli, C., Hansell, D.A., D’Alcalà, M.R., 2013. Influence of stratification on marine dissolved organic carbon (DOC) dynamics: the Mediterranean Sea case. Prog. Oceanogr. 119, 68-77.

Santinelli, C., Nannicini, L., Seritti, A., 2010. DOC dynamics in the meso and bathypelagic layers of the Mediterranean Sea. Deep Sea Res. Pt. II Top. Stud. Oceanogr. 57 (16), $1446-1459$.

Shimotori, K., Omori, Y., Hama, T., 2009. Bacterial production of marine humic-like fluorescent dissolved organic matter and its biogeochemical importance. Aquat. Microb. Ecol. 58, 55-66.

Specchiulli, A., Bignami, F., Marini, M., Fabbrocini, A., Scirocco, T., Campanelli, A. Penna, P., Santucci, A., D'Adamo, R., 2016. The role of forcing agents on biogeochemical variability along the southwestern Adriatic coast: the Gulf of Manfredonia case study. Estuar. Coast. Shelf S. 183, 136-149.

Spencer, R.G., Butler, K.D., Aiken, G.R., 2012. Dissolved organic carbon and chromophoric dissolved organic matter properties of rivers in the USA. J. Geophys. ResBiogeosci. 117 (G3), 3001.

Stedmon, C.A., Bro, R., 2008. Characterizing dissolved organic matter fluorescence with parallel factor analysis: a tutorial. Limnol. Oceanogr.-Meth. 6 (11), 572-579.

Stedmon, C.A., Markager, S., 2005a. Resolving the variability in dissolved organic matter fluorescence in temperate estuary and its catchment using PARAFAC analysis. Limnol. Oceanogr. 50 (2), 686-697.

Stedmon, C.A., Markager, S., 2005b. Tracing the production and degradation of autochthonous fractions of dissolved organic matter by fluorescence analysis. Limnol. Oceanogr. 50 (5), 1415-1426.

Stedmon, C.A., Markager, S., Bro, R., 2003. Tracing dissolved organic matter in aquatic environments using a new approach to fluorescence spectroscopy. Mar. Chem. 82, 239-254.

Sun, Q., Wang, C., Wang, P., Hou, J., Ao, Y., 2014. Absorption and fluorescence characteristics of chromophoric dissolved organic matter in the Yangtze Estuary. Environ. Sci. Pollut. Res. 21 (5), 3460-3473.

Suttle, C.A., 2005. Viruses in the sea. Nature 437 (7057), 356.

Vaquer-Sunyer, R., Duarte, C.M., 2008. Thresholds of hypoxia for marine biodiversity. Proc. Natl. Acad. Sci. USA 105 (40), 15452-15457.

Vignudelli, S., Santinelli, C., Murru, E., Nannicini, L., Seritti, A., 2004. Distributions of dissolved organic carbon (DOC) and chromophoric dissolved organic matter (CDOM) in coastal waters of the northern Tyrrhenian Sea (Italy). Estuar. Coast. Shelf S. 60 (1), 133-149.

Vodacek, A., Hoge, F., Swift, R.N., Yungel, J.K., Peltzer, E.T., Blough, N.V., 1995. The use of in situ and airborne fluorescence measurements to determine UV absorption coefficients and DOC concentrations in surface waters. Limnol. Oceanogr. 40, 411-415.

Wang, S.L., Chen, C.T.A., Huang, T.H., Tseng, H.C., Lui, H.K., Peng, T.R., Kandasamy, S., Zhang, J., Yang, L.Y., Gao, X.L., Lou, J.Y., Kou, F.W., Chen, X.G., Ye, Y., Lin, Y.J., 2018. Submarine Groundwater Discharge helps making nearshore waters heterotrophic. Sci. Rep. 8, 1-10.

Watanabe, K., Kuwae, T., 2015. How organic carbon derived from multiple sources contributes to carbon sequestration processes in a shallow coastal system? Glob. Chang. Biol. 21 (7), 2612-2623. 
Weishaar, J.L., Aiken, G.R., Bergamaschi, B.A., Fram, M.S., Fujii, R., Mopper, K., 2003. Evaluation of specific ultraviolet absorbance as an indicator of the chemical composition and reactivity of dissolved organic carbon. Environ. Sci. Technol. 37 (20), $4702-4708$.

Xing, H.Y., Sun, S., Ma, Y.Q., Bai, Y.Y., Jin, Y., Liu, Y.H., Qin, H.W., Li, B., 2013. Annual variation of nutrients and influential factors on it in Sishili Bay. Mar. Sci. Bull. 32 (1), 53-57.

Xu, H., Cai, H., Yu, G., Jiang, H., 2013. Insights into extracellular polymeric substances of cyanobacterium Microcystis aeruginosa using fractionation procedure and parallel factor analysis. Water Res. 47 (6), 2005-2014.

Xu, H., Guo, L., 2017. Molecular size-dependent abundance and composition of dissolved organic matter in river, lake and sea waters. Water Res. 117, 115-126.

Xu, H., Guo, L., 2018. Intriguing changes in molecular size and composition of dissolved organic matter induced by microbial degradation and self-assembly. Water Res. 135, 187-194.

Xu, H., Houghton, E.M., Houghton, C.J., Guo, L., 2018. Variations in size and composition of colloidal organic matter in a negative freshwater estuary. Sci. Total Environ. 615, 931-941.

Yamashita, Y., Boyer, J.N., Jaffé, R., 2013. Evaluating the distribution of terrestrial dissolved organic matter in a complex coastal ecosystem using fluorescence spectroscopy. Cont. Shelf Res. 66, 136-144.

Yamashita, Y., Jaffé, R., Maie, N., Tanoue, E., 2008. Assessing the dynamics of dissolved organic matter (DOM) in coastal environments by excitation and emission matrix fluorescence and parallel factor analysis (EEM-PARAFAC). Limnol. Oceanogr. 53 1900-1908.

Yamashita, Y., Panton, A., Mahaffey, C., Jaffe, R., 2011. Assessing the spatial and temporal variability of dissolved organic matter in Liverpool Bay using excitation-emission matrix fluorescence and parallel factor analysis. Ocean Dyn. 61 (5), 569-579.

Yamashita, Y., Tanoue, E., 2008. Production of bio-refractory fluorescent dissolved organic matter in the ocean interior. Nat. Geosci. 1, 579-582.

Yamashita, Y., Tsukasaki, A., Nishida, T., Tanoue, E., 2007. Vertical and horizontal distribution of fluorescent dissolved organic matter in the Southern Ocean. Mar. Chem. 106 (3-4), 498-509.

Yamashita, Y., Tanoue, E., 2004. In situ production of chromophoric dissolved organic matter in coastal environments. Geophys. Res. Lett. 31 (14), 1-4.

Yang, L., Chen, C.T.A., Hong, H., Chang, Y.C., Lui, H.K., 2015. Mixing behavior and bioavailability of dissolved organic matter in two contrasting subterranean estuaries as revealed by fluorescence spectroscopy and parallel factor analysis. Estuar. Coast. Shelf S. 166, 161-169.

Yang, L., Chen, C.T.A., Lui, H.K., Zhuang, W.E., Wang, B.J., 2016. Effects of microbial transformation on dissolved organic matter in the East Taiwan Strait and implications for carbon and nutrient cycling. Estuar. Coast. Shelf S. 180, 59-68.

Yao, X., Zhang, Y., Zhu, G., Qin, B., Feng, L., Cai, L., Gao, G., 2011. Resolving the variability of CDOM fluorescence to differentiate the sources and fate of CDOM in Lake Taihu and its tributaries. Chemosphere 82 (2), 145-155.

Zeri, C., Besiktepe, S., Giannakourou, A., Krasakopoulou, E., Tzortziou, M., Tsoliakos, D., Pavlidou, A., Mousdis, G., Pitta, E., Scoullos, M., Papathanasiou, E., 2014. Chemical properties and fluorescence of DOM in relation to biodegradation in the interconnected Marmara-North Aegean Seas during August 2008. J. Mar. Syst. 135, 124-136.

Zhai, W.D., Zheng, N., Huo, C., Xu, Y., Zhao, H.D., Li, Y.W., Zang, K.P., Wang, J.Y., Xu, X.M., 2014. Subsurface $\mathrm{pH}$ and carbonate saturation state of aragonite on the Chinese side of the North Yellow Sea: seasonal variations and controls. Biogeosciences 11 (4), 1103-1123.

Zhang, Y., Yin, Y., Feng, L., Zhu, G., Shi, Z., Liu, X., Zhang, Y., 2011. Characterizing chromophoric dissolved organic matter in Lake Tianmuhu and its catchment basin using excitation-emission matrix fluorescence and parallel factor analysis. Water Res. 45 (16), 5110-5122.

Zhang, Y.L., Van Dijk, M.A., Liu, M.L., Zhu, G.W., Qin, B.Q., 2009. The contribution of phytoplankton degradation to chromophoric dissolved organic matter (CDOM) in eutrophic shallow lakes: field and experimental evidence. Water Res. 43 (18), 4685-4697.

Zheng, H., Yan, Z., Chen, J., Jin, H., Chen, C.T.A., Liu, M., Yan, Z., Ji, Z., 2018. Seasonal variations of dissolved organic matter in the East China sea using EEM-PARAFAC and implications for carbon and nutrient cycling. Sustainability 10 (5), 1444.

Zhou, F., Gao, X., Song, J., Chen, C.T.A., Yuan, H., Xing, Q., 2018. Absorption properties of chromophoric dissolved organic matter (CDOM) in the East China Sea and the waters off Eastern Taiwan. Cont. Shelf Res. 159, 12-23.

Zhou, Z., Guo, L., Minor, E.C., 2016. Characterization of bulk and chromophoric dissolved organic matter in the Laurentian Great Lakes during summer 2013. J. Gt. Lakes Res. 42 (4), 789-801.

Zsolnay, A., Baigar, E., Jimenez, M., Steinweg, B., Saccomandi, F., 1999. Differentiating with fluorescence spectroscopy the sources of dissolved organic matter in soils subjected to drying. Chemosphere 38 (1), 45-50. 